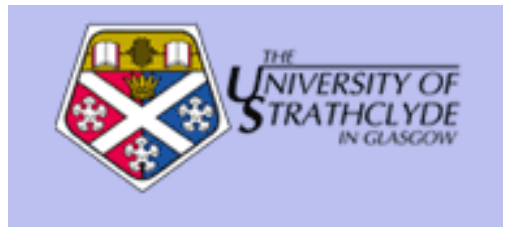

Darby, J. and Melitz, J. (2008) Social expenditure and automatic stabilisers in the OECD. Economic Policy, 23 (56). pp. 715-756. ISSN 0266-903X

http://strathprints.strath.ac.uk/8709/

Strathprints is designed to allow users to access the research output of the University of Strathclyde. Copyright (C) and Moral Rights for the papers on this site are retained by the individual authors and/or other copyright owners. You may not engage in further distribution of the material for any profitmaking activities or any commercial gain. You may freely distribute both the url (http://strathprints.strath.ac.uk) and the content of this paper for research or study, educational, or not-for-profit purposes without prior permission or charge. You may freely distribute the url (http://strathprints.strath.ac.uk) of the Strathprints website.

Any correspondence concerning this service should be sent to The Strathprints Administrator: eprints@cis.strath.ac.uk 


\title{
Social Spending and Automatic Stabilisers in the OECD
}

\author{
Julia Darby and Jacques Melitz \\ University of Strathclyde, Glasgow and CPPR; Heriot Watt University, Edinburgh, CREST \\ and CEPR
}

\section{Summary}

The macroeconomic literature on automatic stabilisation tends to focus on taxes and dismiss the relevance of government expenditure except for unemployment compensation. Our results go sharply contrary to this view. We engage in an empirical analysis of 20 OECD countries from 1980-2001 and find that age-and health-related social expenditure as well as incapacity benefits all react to the cycle in a stabilising manner. While possibly new in the macro literature, this conforms to many results in studies in labour economics. In the individual country studies, the cyclical sensitivity of the other items of social spending emerges less clearly than that of unemployment compensations. Thus, as a distinct possibility in the study, the mechanisms underlying automatic stabilisation may vary by country.

Preliminary version of a paper prepared for the $47^{\text {th }}$ Panel Meeting of Economic Policy in Ljubljana on 18-19 April, 2008. We are grateful to three anonymous referees for helpful comments. Simon Wren Lewis, participants at the meetings of the European Monetary Forum in Cardiff in 2007 and the 2006 MMF Conference in York and seminar participants at Leeds, Loughborough and Strathclyde also provided useful feedback and suggestions on an earlier version of this work. In addition we would like to thank Max Laidaique of the OECD for his help in clarifying a number of issues regarding the Social Expenditure database. 


\section{INTRODUCTION}

The macroeconomic literature on automatic stabilisation tends to focus on taxes and to dismiss the relevance of any government spending besides unemployment compensation. In this study, we test this fundamental view. We examine the cyclical responsiveness of government expenditure on health, retirement benefits, incapacity benefits and sickness pay as well as unemployment compensation and we do so by pulling together data from the OECD Social Expenditure database and from the OECD Economic Outlook database. (Melitz (2006) relied exclusively on the OECD national income database in earlier related work.) The results go sharply contrary to the idea that unemployment compensation is the sole element of social expenditure that responds to the cycle. We find that expenditures on health, retirement and incapacity also react prominently to the cycle. Furthermore, these spending categories do so in a stabilising manner. Thus they enhance total automatic stabilisation. The policy implications of this finding are broad since much previous analysis of discretionary fiscal policy rests on official figures for automatic stabilisation. If those figures ignore some sources of automatic stabilisation, automatic stabilisation is higher and the results of those studies concerning discretionary fiscal policy fall into question. In addition, the danger that members of the European Union would violate the 3 percent limit on deficit spending of the Stability and Growth Pact during recessions is greater.

A focus on taxes and unemployment compensation simply pervades the current textbook literature in macroeconomics in discussing automatic stabilisation. There may be an occasional vague reference to counter-cyclical income support coming from other government spending besides unemployment compensation. However, with the outstanding exception of Hall and Taylor (1991, chapter 13, which subsequently became Hall and Pappell (2005), chapter 13), unemployment compensation is the only spending item that receives mention. The textbooks are representative. In defending the exclusive consideration of unemployment compensation as a counter-cyclical spending category (except for small items like food stamps), Auerbach and Feenberg (2000), for example, say: "The logic is straightforward: discretionary spending is, after all, discretionary, not automatic, and interest payments and the most important mandatory spending programs, Social Security and Medicare, are based on longer-term factors" (p.52). Likewise, Gali and Perotti (2003) maintain: "Among primary expenditures [apart from interest payments], only unemployment benefits probably have a non-negligible built-in response to output fluctuations." Perotti (2002) is more explicit: "Items like old age, disability and incapacity pensions - the bulk of transfers to households - do not have built-in mechanisms that make them respond automatically to changes in employment or output contemporaneously. Unemployment compensation obviously does." 


\subsection{Preliminaries}

We will make only one concession to these views though an important one: namely, that unemployment compensation is possibly more prevalent in automatic stabilisation than the other items of social spending in the OECD. However, even if this were true, it would hardly mean that the other social spending items do not play a role. In particular, the idea these other contributions can be disregarded as lacking theoretical foundation does not stand up to examination. The literature on labour economics is replete with theoretical arguments for systematic influences of the cycle on retirement benefits, invalidity pay and sickness pay. As regards invalidity pay and sickness pay, the hypotheses in labour economics are contradictory but that does not call for a draw. We know of no study of the cyclical response of social spending on health care. But there is an active literature on the impact of the cycle on health (not health care), not in labour economics but in the field of public health, and this literature finds that health is highly countercyclical - not only in the US, but also in a number of European countries, and not only recently, but going back to the first half of the twentieth century (see, for example, Tapia Granados (2005a)).

The reasons for entertaining the possibility of automatic cyclical responses of retirement benefits, invalidity pay, paid sick leave and social health spending are important to indicate at the outset. In the case of retirement benefits, there are strong forces that act to lower the average age of retirement in recessions, thereby causing the numbers of retirees to exceed the long-term trend, and to raise the average age of retirement in expansions, thereby causing the number of retirees to fall below trend. A counter-cyclical movement in pension expenditure can easily result even if the same people who retire in recessions do not necessarily return to work in expansions. Supporting evidence abounds. Darby, Hart and Vecchi (2001) report a significant impact of the cycle on labour participation rates for both sexes, especially in the over 54 age group in France, Japan, Sweden and the US. Blanchard and Diamond (1990) similarly show that following a negative output shock, the highest consequent movement of workers from employment to non-employment is concentrated among teenagers and people over 65 in the US. Rebick (1994) shows that new recipients of retirement benefits rise during recessions and fall during expansions in Sweden and Japan. Of course, since retirement decisions are long term, labour participation decisions alone may not adequately explain the observed countercyclical behaviour of pension payments (see Mitchell and Fields (1984) and Haveman and Wolfe (1984)). However, demand-side factors reinforce the result. Unemployment compensation is a major pathway to retirement in many countries, including Sweden, Belgium, France, Germany and Japan, which would indicate that involuntary loss of employment in recessions contributes to retirement. Coile and Levine (2006) (who cite studies for each of the preceding countries) show that downturns increase retirement decisions in the U.S. Hutchens (1999) has also recently pointed out that firms have strong incentives to encourage early retirement and to lay off older workers during recessions in many Western countries on the basis of the structure of payroll taxes, contributions to health insurance, private 
pension plans and social security systems. Since Hutchens' writing, Hakola and Utusitalo (2005) have confirmed the importance of firm behaviour in contributing to the counter-cyclical movement of retirements in Finland. All of these results accord with our cross-country findings. ${ }^{1}$

On the connected questions of paid sick leave and incapacity related benefits, the labour literature is divided about the expected cyclical response. There is a section that advances the theoretical argument, owing largely to Shapiro and Stiglitz (1984), that when times are bad, shirking is dangerous. Vulnerable workers - those on temporary contracts or with a history of health problems - will be particularly loath to report sick (see Arai and Skogman Thoursie (2005) and Barmby, Ercolani and Treble (2004)). When times are good, workers are able to report sick with less fear of unemployment. Also, in good times people with permanent health problems have less difficulty in holding down a job. Furthermore, since the pace of work is greater, there may be more work accidents, especially in dangerous industries. This literature points to an inverse relationship between rates of absenteeism and rates of unemployment, and interprets this negative relationship as indicating that absenteeism is pro-cyclical (see Leigh (1985), Boone and van Ours (2002), Khan, Gerdtham and Jansson (2004) and Kaivento (1997) for more references, and see also Barmby, Ercolani and Treble (2002) for general crosscountry evidence on sickness-related absence). The previous literature also relates to paid sick leave far more than incapacity related benefits.

On the other hand, there is an opposing literature arguing that when layoffs rise during recessions, the people with a choice between declaring illness, incapacity or unemployment will base their decision on the rate and the duration of replacement of wages through social benefits. Thus, more people with health problems will report ill and incapacitated during bad times. In this case, the supporting evidence, which relates to incapacity benefits as well as sick pay, tends to show that sick pay and incapacity benefits move together over the cycle, along with unemployment compensation. This evidence comes mostly from studies that compare the performance in depressed and prospering regions within the same country. McVicar (2006) provides a useful review article. This literature tends to emphasise the fact that changes in social legislation over the last 30 years or more have facilitated the ability to claim these benefits, and have resulted in secular increases in the percentages of the labour force receiving sickness and Incapacity Related Cash Benefits in the West, despite the absence of evidence that health has declined. See Bound and Burkhauser (1999) and Beatty, Fothergill and Macmillan (2000) (who refer to the 'hidden sick'). Our results favour this last interpretation of the stabilising cyclical behaviour for incapacity benefits but are inconclusive about sick pay.

In the light of the conflicting theory and results concerning the cyclicality of incapacity and sickness related benefits, one methodological issue bears attention at once. The part

\footnotetext{
${ }^{1}$ As an interesting qualification, Cohen and Follette (2000, note 35) observe that any cyclical movement in retirement benefits will be partly muted by the reduction of retirement benefits accruing to people who retired early in previous recessions once they have reached statutory retirement age. This offsetting effect may arise for a while (perhaps in a pro-cyclical manner), following a fall in the average age of retirement, and may generally modify the cyclical movement. But we cannot follow Cohen and Follette in dismissing the whole issue of the counter-cyclical behaviour of retirement benefits without further investigation on this ground alone.
} 
of the literature arguing that paid sick leave is pro-cyclical commonly treats the rate of unemployment as the indicator of the cycle. Leigh (1985) does so in explaining the behaviour of absenteeism; Boone and van Ours (2002) do so too in explaining that of incapacity pay; as do Khan, Gerdtham and Jansson (2004) in explaining both sick pay and incapacity pay. However, both theory and evidence show that the numbers of the unemployed, recipients of paid sick leave and recipients of incapacity pay are determined simultaneously. In this connection, Black, Daniel and Sanders (2002) and Autor and Duggan (2003) are important in providing detailed analyses of the impact of the disability program on the long term rate of unemployment in the US. See also Beatty, Fothergill and Macmillan (2000) and Holmlund (2004) for related theoretical discussion. Thus, there is a considerable objection to treating unemployment as the measure of the cycle in explaining illness and disability pay. This treatment poses a simultaneity problem, and the problem becomes all the greater if, as in the relevant literature, the level rather than the first difference of unemployment is adopted as the measure of the cycle. We take our measure of the cycle to be the output gap or the ratio of output to potential output (an alternative measure of the gap) rather than the unemployment rate. We shall also use first differences rather than levels in order to focus attention upon short term responses, and we shall take steps to allow for the potential simultaneity of fiscal variables and the output gap.

As regards health expenditure, there is considerable interest in labour economics in the relation of health and health insurance to the retirement decision as such (see Blau and Gilleskie (2001), Disney, Emmerson and Wakefield (2003), Dwyer and Mitchell (1999) and Gruber and Madrian (1995). However, the relation of health spending to the cycle has not come in for special study. Yet if health care is cyclical, government spending on health will probably be so too. As indicated already, related research comes from specialists in public health and focuses on health not health spending. In addition, the results are not necessarily intuitive. We might think that recessions would have detrimental effects on the health of those losing jobs or in fear of losing jobs, largely for socio-psychological reasons (see for example Neumayer (2005)). But the main results go the other way: they say that health is counter-cyclical and worsens during booms (Gerdtham and Ruhm (2006), Ruhm (2000, 2001, 2003, 2005a,b, 2006), Ruhm and Black (2002), Tapia Granados (2005a,b)). The key factor is that the relevant studies concern the impact of the cycle on the total population, whereas the unemployed and the precariously employed only form a minority in all phases of the cycle. Accordingly, the proposed reasons for worsening health during expansions are longer working hours, jobrelated stress, less physical activity, less sleep, and the direct effects of some physically dangerous work activities as well as greater consumption of health-damaging goods (tobacco, alcohol and saturated fats). The typical measure of health in these studies is mortality at different ages from different causes (including crime and traffic accidents). However, of course, movements in government spending on health could deviate widely from movements in health since the spending depends on health care, which though clearly related to health is not the same. Much health care can be postponed. Even if people are healthier on average in recessions, the lower value of leisure at these times 
could lead to greater health care, particularly in cases of coverage by health insurance. Indeed, the extra health care when time has a lower opportunity cost could be an additional reason for the better health of the population during recessions. ${ }^{2}$ As regards this line of thinking, Jacques Mairesse has suggested the interesting analogy to firms' treatment of physical capital to us. During booms firms tend to fail to replace machines and other equipment, preferring to bring older standby equipment into operation, and devote minimal resources to upkeep and repair. Then when business slows down, they undertake major repairs and renovations. The logic is the same.

A further, but lesser explanation for countercyclical movements in health spending is that more people than usual may become eligible for government-sponsored health programs during recessions. This may be true even in countries with universal support of health care, since governments may require lower co-payments for those on low incomes, the disabled and the unemployed. However, our results about health spending go strongly enough in the counter-cyclical direction that we consider this factor to be less important than the earlier one of general decisions about health care in the population of the eligible, especially the older part of the population, as we shall emphasize later on.

In sum, theory and empirical evidence both argue for the possible role of every major category of social spending in our discussion in automatic stabilisation. As we have already indicated, however, our results also show that the cyclical relevance of pensions, health spending, incapacity and sickness benefits vary more by country than that of unemployment compensation. In a recent OECD working paper, Girouard and André (2005) dismiss any items of social spending besides unemployment compensation on the ground that "data coverage and cyclical variation are uneven across time and countries" (p. 20). The other items they cite are subsidized employment and early retirement. However, if our figures for automatic stabilisation are to be limited to the mechanisms that exist for decades and apply everywhere, how much faith can we have in any national application?

\subsection{Key results and the organisation of the paper}

We shall study automatic stabilisation with a specification expressed both in levels and ratios. That is, we shall consider both the automatic impact of an extra euro of output gap on extra cents of budget surplus, and the automatic impact of an extra percentage-point of output gap on an extra fraction of a percentage-point of the budget surplus as a proportion of GDP. However, unlike the rest of the literature, we shall estimate both specifications separately. This is an important point. With one exception, others have estimated automatic stabilisation strictly in levels, even though they have often gone on

\footnotetext{
${ }^{2}$ Ruhm (2000) makes many of the same points in a study of the impact of the cycle on population health as such. As he notes too, the relative price of health might be lower in recessions. But this could affect health spending either way depending on the elasticity of demand.
} 
to reason in ratios. The one exception is Arreaza, Sorensen and Yosha (1999), who reason and estimate strictly in ratios. We shall return shortly to this point.

In the case of levels, overall we find that the extent of automatic stabilisation through all elements of social expenditure is about 3.25 times larger than the part coming from unemployment compensation alone. Every dollar of an output gap yields around 4 cents of unemployment compensation in our 20-country OECD panel. However, there is also 9 cents of additional social spending on health, retirement, and incapacity benefits. Moreover, either health spending or retirement benefits taken alone are as important as unemployment compensation. When we conduct the study in ratios, we find that social spending contributes about 4 times more to automatic stabilisation than unemployment compensation. Specifically, a one percentage-point rise in the output gap increases the ratio of social spending to output by around 19 percent of one percentage-point while unemployment compensation contributes a little less than 5 percentage-points to the 19 . The rest comes from the previously listed sources. But health expenditure is as important as unemployment compensation, and pensions are the most important of all, accounting for over a third of the entire cyclical response of social spending.

With regard to automatic stabilisation, regardless of levels or ratios, all things considered, our results imply larger numbers than suggested in the previous literature. The usual estimates of aggregate automatic stabilisation in the OECD are expressed in levels and about .5. We obtain about .61 as our principal result. In light of our wider definition of automatic stabilisation and the greater number of stabilising influences in our work, this may not be surprising. Stabilisation also comes mostly from the tax side in our estimates for levels, in accordance with usual views. In fact taxes are the source of .44 of the .61 total, and the rest is dominated by social expenditure. In the case of ratios or percentage-points of output, we find less automatic stabilisation - close to .4. However, taxes contribute nothing and social spending explains around half the estimated response. Broadly speaking, these results in ratios agree well with Arreaza, Sorensen and Yosha (1999), who were to our knowledge the first to estimate automatic stabilisation in ratios to output. They too found taxes to be of little importance and spending to be the basic stabilising force.

The next section sets out the framework for our analysis and compares our approach to the dominant official one to estimating automatic stabilisation. Fuller details of our econometric procedures are presented in an appendix. In the subsequent section, we shall present the basic results for our entire panel of 20 countries both in the form of levels and ratios. Next, we will present some robustness tests regarding smaller country subsamples and across discrete sub-periods. We will also provide some tests of symmetry of responses in recessions and expansions and of the linearity of responses to the cycle. Following, we shall provide and discuss individual-country results. As a separate robustness test, we will also offer an estimate of the core model using the latest general release of coherent data for social spending from the OECD (this release, which was made available at the end of 2007, provides two more years of data, thus allowing estimation to go up to 2003). Finally, we shall offer some discussion of the policy and research implications of our results. A short concluding section will close the paper. 


\section{OUR FRAMEWORK OF ANALYSIS}

\subsection{The official method of estimating automatic stabilisation}

The official method of estimating automatic stabilisation used by the OECD, the European Commission and the US Congressional Budget Office alike, distinguishes 5 different elements of the government budget balance and then studies each of them independently. These are: household direct taxes, business direct taxes, social security contributions, indirect taxes and unemployment compensation (see Giorno et al. (1995)). The official practice is to estimate the cyclical response of the 5 respective bases on which these 5 tax and spending items rest, and then to apply the national tax code or else to assume a unitary elasticity of response to the base in order to derive the 5 items, whichever seems more appropriate. Van den Noord (2000) offers a clear and detailed review of the method (in the OECD version, used by the EC as well). To quote from his summary:

"First, the elasticities of the relevant tax bases and unemployment with respect to (cyclical) economic activity, i.e. the output gap, are estimated through regression analysis. Next, the elasticities of tax proceeds or expenditure [unemployment compensation] with respect to the relevant bases are extracted from the tax code or simply set to unity in cases where proportionality may be assumed. These two sets of elasticities are subsequently combined into reduced-form elasticities that link the cyclical components of taxes and expenditure to the output gap." 3

This method deals with automatic stabilisation expressed entirely in levels. But research often focuses on ratios. It is easy to see why. Stabilisation policy relates to smoothing economic performance or keeping output close to potential, and consequently, the problem of fiscal policy is often seen as keeping the ratio of actual output to potential output close to one. Given this view, the critical fiscal policy variable becomes the ratio of the net budget balance to output, and the critical issue is to determine how the ratio responds to the cycle aside from any discretionary behaviour by the authorities. However, when the issue becomes one of ratios, it is fairly standard practice to continue using the official estimates of automatic stabilisation to correct the budget balance in levels for non-discretionary responses and then to simply divide the derived discretionary response by output in order to obtain the ratios of cyclically adjusted figures to output or potential output. The European Commission adopts this

\footnotetext{
${ }^{3}$ There have appeared two particularly sophisticated applications of the method, both of which we have already had occasion to mention. Cohen and Follette (2000) investigated the response of the 5 relevant tax and spending items in the US in the frequency domain in order to test the significance of the responses at business cycle frequencies. Girouard and André (2005) introduced some lag structure in the cyclical adjustment of the separate items and made some use of the method of seemingly unrelated regressions in their study dealing with numerous OECD members.
} 
approach in its annual surveys of country members' adherence to the Stability and Growth Pact. But the Commission is not alone. Two prominent recent academic examples are Taylor (2000) and Galí and Perotti (2003). Both explicitly proceed from cyclically adjusted figures in levels based upon official numbers (from the U.S. Congressional Budget Office in one case, the OECD in the other) to subsequent division by output (Taylor) or potential output (Galí and Perotti) in order to analyze the behaviour of discretionary fiscal policy.

These practices would be fine if the official figures for the cyclically adjusted budget were hard facts. Even if these figures are not hard facts but only estimates, the practices would still be acceptable if the division of the official numbers was by potential output rather than observed output and potential output was perfectly deterministic and not subject to any shocks. From a technical econometric standpoint, the estimates are not efficient. On a simple intuitive plane, they are not transparent. If the issue is the impact of the ratio of output to potential on the ratio of the net government surplus to output, why not estimate in ratios directly?

\subsection{Our approach}

In our research, we shall deviate from the foregoing practices in many ways, which we set out fully in an appendix, but the deviation on which we would like to focus at once is our decision to present estimates obtained from specifications both in levels and ratios.

Take a simple case where taxes move proportionately with output but expenditures stay fixed, and suppose there is a contraction in output. Some automatic stabilisation would result from the fall in taxes and some would result from the failure of government spending to decline with the fall in output. Suppose we measure automatic stabilisation in levels. In that case, we will attribute all of the automatic stabilisation to taxes since taxes fall while output stays the same. Suppose we measure automatic stabilisation in ratios. Then we would attribute all of the automatic stabilisation to government spending since the ratio of government spending to output rises while the ratio of taxes to output stays the same. Some mix of the two assessments would be correct. However, only a general structural model would tell us the right mix. Such a model is beyond our ambitions. However, since one estimate favours the tax contribution while the other favours the spending contribution, there would seem to be a case for examining both estimates rather than only one.

Another argument is important. The proper structural model to use in assessing automatic stabilisation would be a complicated one with many different tax and spending items responding differently to output and the output gap. By general agreement, on the tax side, all individual items respond positively to movements in output, but they may do so proportionately, more than proportionately or less than proportionately, and may do so in a linear or a non-linear manner. These responses also do not necessarily depend on deviations from trend and could be similar for changes in output and the output gap. On the spending side, some individual items may not vary with output, while others do, and 
those that do - like unemployment compensation and retirement benefits - will often vary differently depending on the size of the output gap. Even the signs of the movements may differ. Thus a common specification of all of the equations for the individual budgetary items - especially those on the revenue and spending side - is not exactly right. Nevertheless, it is general practice to adopt a common linear approximation to all of the equations (when more than a single equation - namely, for the net government surplus - is even present). In addition, the general practice is to estimate reduced forms in which any control for contemporaneous reciprocal effects of the explanatory variables on the tax and spending equations may or may not be present. We will follow the general practice in using a common linear approximation to all of the equations in a reduced form, but having done so, there are two prevalent sorts of linear approximations to consider in the literature: one in levels and one in ratios. The one in levels corresponds closely to the habits of official bodies in estimating automatic stabilisation. The one in ratios is quite close to Arreaza, Sorensen and Yosha (1999) and Aghion and Marinescu (2007), but also to Gali and Perotti and Taylor after they have corrected for automatic stabilisation. We think that these two linear approximations do not reflect any fundamental opposition about the right underlying structural model. In these circumstances, it only seems right to present results for both approximations, while interpreting them with care, rather than choosing only one from the start.

The two alternative estimating equations for the individual budgetary items in our estimates will then be:

$$
\begin{aligned}
& \Delta \mathrm{x}_{\mathrm{it}}=\alpha_{\mathrm{o}}+\beta_{1} \Delta_{\mathrm{t}}\left(\mathrm{Y}_{\mathrm{t}}-\mathrm{Y}_{\mathrm{t}}^{*}\right)+\beta_{2} \Delta \pi_{\mathrm{t}}+\beta_{3} \mathrm{r}_{\mathrm{Lt}}+\lambda_{\mathrm{j}} \mathrm{c}_{\mathrm{jt}}+\varepsilon_{\mathrm{it}} \\
& \Delta\left(\mathrm{x}_{\mathrm{it}} / \mathrm{Y}_{\mathrm{t}}\right)=\alpha_{\mathrm{o}}+\beta_{1} \Delta\left(\mathrm{Y}_{\mathrm{t}} / \mathrm{Y}_{\mathrm{t}}^{*}\right)+\beta_{2} \Delta \pi_{\mathrm{t}}+\beta_{3} \mathrm{r}_{\mathrm{Lt}}+\lambda_{\mathrm{j}} \mathrm{c}_{\mathrm{jt}}+\varepsilon_{\mathrm{it}} \\
& \text { for } \mathrm{i}=1 \ldots 15
\end{aligned}
$$

The $\mathrm{x}_{\mathrm{i}}$ variables refer to individual sorts of receipts and expenditures. There are then as many equations (1) and (2) as the number of $x_{i}$ variables (that is, 15 of them). $Y$ is output, $\mathrm{Y}^{*}$ is potential output, $\pi$ is the rate of inflation, and $\mathrm{r}_{\mathrm{L}}$ is the long term interest rate. Inflation and the nominal rate of interest are present, in addition to the output gap $\left(\mathrm{Y}-\mathrm{Y}^{*}\right.$ or $\left.\mathrm{Y} / \mathrm{Y}^{*}\right)$, as influences that may affect government revenues and expenditures fairly automatically, even within a year. $c_{j}$ represents a number of extra variables $j$ that we introduced to improve the statistical accuracy of our estimates and $\lambda_{j}$ are their respective coefficients (full details are provided in the appendix). In addition, since individual taxes and spending items may have reciprocal effects on the output gap, even within an observation period as short as a calendar year (Blanchard and Perotti (2002)), like Gali and Perotti (2003), we allow for the potential endogeneity of the output gap. This requires three more equations besides the previous 15 for the individual revenue and spending variables in order to control for the reciprocal influences of the dependent variables $\left(\mathrm{x}_{\mathrm{i}}\right.$ and $\left.\mathrm{x}_{\mathrm{i}} / \mathrm{Y}\right)$ on the output gap, inflation and the interest rate. All in all we shall then have 18 equations to estimate and we shall estimate them as a system. The responses of the different sorts of government receipts and expenditures to the cycle depend on distinct legal schedules and regulations of varying complexity that change 
over time and have different periods of collection and disbursement. Thus, our econometric procedure seems to us preferable to the official method of relying heavily on inferences from legal rules in obtaining estimates for the individual items.

The critical coefficient in the system is obviously $\beta_{1}$, which relates to the impact of the output gap, $\mathrm{Y}-\mathrm{Y}^{*}$ in levels and $\mathrm{Y} / \mathrm{Y}^{*}$ in ratios. Since $\beta_{1}$ captures a contemporaneous effect of the cycle, we assume that it does not reflect discretionary policy action. This seems justified since changes in tax regulations take significant time, as do fresh spending decisions. The literature on fiscal policy underlines these delays (see, for example, Canzoneri, Cumby and Diba (2002) and the European Commission (2004)). By using first differences in equations (1) and (2), we also hope to focus better on the impact effect, or the short run response. Gali and Perotti (2003) chose to conduct the analysis of discretionary fiscal policy in levels instead of first differences on the grounds that the usual simple theoretical models of the impact of fiscal policy on the economy are stated in levels. However, in our view, working in levels may confuse structural and cyclical responses. This problem may not have concerned Gali and Perotti as much as us since they were interested in discretionary fiscal policy and structural changes in the net government surplus are part of such policy (along with deliberate responses to the cycle). However, as we are concerned exclusively with automatic stabilisation, excluding any long run structural influence seemed essential to us. So we deemed the use of first differences preferable. Issues of stationarity also lead us to prefer the differenced approach.

The critical coefficient $\beta_{1}$ has a simple interpretation. Suppose $\beta_{1}$ is 0.1 in one of the equations (1). This says that an increase in the output gap $Y-Y^{*}$ of one euro raises the relevant receipt or expenditure item by 10 cents. Now suppose $\beta_{1}$ is 0.1 in one of the ratio equations (2). This says that a percentage-point increase in the output gap $\mathrm{Y} / \mathrm{Y}^{*}$ raises the relevant receipt or expenditure item by $10 \%$ of one percentage-point relative to output. In both cases, $\beta_{1}$ is therefore a pure number (though not an elasticity). ${ }^{4}$ Note that $\mathrm{x}_{\mathrm{i}}, \mathrm{Y}$ and $\mathrm{Y}^{*}$ can all remain in national currencies. In addition, they can all be stated in nominal terms since the same deflator applies to all of them.

In closing, we should mention that we still cannot rule out the possibility that our critical coefficient $\beta_{1}$ partly reflects some discretionary policy response since some such response could occur within the same calendar year. Progress on this important issue, it seems to us, will require introducing discretionary fiscal policy simultaneously into the analysis. We hope to do so in the future. Nonetheless, we may observe for the moment that if there is any discretionary behaviour in our estimates, despite our use of first differences between calendar years and our other precautions, there is little evident reason why it should lead to an exaggeration of the automatic response of health, retirement benefits, incapacity and sickness related benefits as opposed to unemployment compensation and taxes.

\footnotetext{
${ }^{4}$ An elasticity would refer to the effect of a percentage change in the first difference in the output gap on the percentage change in the first difference of $x_{i}$ in one case and the effect of a percentage change in the first difference in the ratio of output to potential output on the percentage change of the first difference in $\mathrm{x}_{\mathrm{i}} / Y$ in the other.
} 


\section{DATA AND RESULTS}

\subsection{Description of the Data}

The data we employ are taken from the separate OECD databases for National Income and for Social Expenditure. The National Income data are from the Economic Outlook database in the 2005:2 release of the OECD compendium CD-ROM. The Social Expenditure database in our analysis is the 2004 release available on the OECD's website, which provides data for each country from 1980 to 2001 at best, and therefore shortens the estimation period that would be possible based on the National Income database. However, a new coherent revision of the Social Expenditure database has recently been made available (in late 2007), which permits us to offer results of our key specification going up to 2003. If we were to restrict ourselves to the countries for which the full 1980-2001 sample is available we would be limited to just 12 countries. In order to maximise degrees of freedom we have employed an unbalanced panel of 20 countries throughout, which give us a total of 344 observations. Our database includes 13 of the 15 members of the European Union in 2001 (the missing EU members are Luxembourg and Greece) and the 7 OECD countries outside the EU are Australia, Canada, Iceland, New Zealand, Norway, Switzerland and the US. We exclude Japan from our main estimates, though not from the individual-country tests, for a reason that we will explain below.

It may be wise to take a general look at the orders of magnitude for the variables on the expenditure side in our study before we turn to the results. Table 1 shows averages and standard deviations of these variables as percentages of total government expenditures or else as percentages of GDP for the 344 observations.

Table 1. Government Spending and its composition

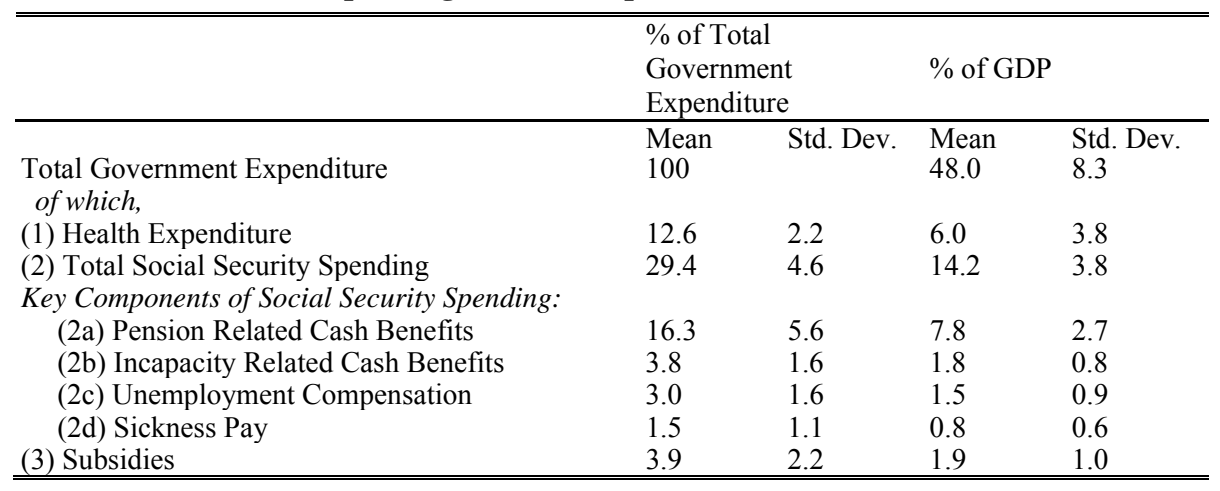

Source: OECD Economic Outlook and Social Expenditure databases and authors' calculations.

The table distinguishes 3 key categories of government social spending based on the published statistics: health expenditures, social security spending and subsidies. A further sub-division of social security spending is made between retirement (old age cash 
benefits including early retirement pension and survivors cash benefits), incapacity benefits (related to disability, occupational injury and disease but excluding temporary paid sick leave), paid sick leave, and unemployment compensation. It is important to keep in mind that the health expenditures represent a class of direct government spending on goods and services and only the rest of social expenditures are transfer payments, either to persons in the case of social security, or to firms in the case of subsidies. We shall essentially limit our interest to the social benefits paid to households and exclusive of subsidies.

As can be seen, retirement cash benefits are by far the largest component of social expenditure, averaging more than $16 \%$ of government spending in the aggregate; health is next, averaging almost $13 \%$. Unemployment compensation is much lower, at $3 \%$. Interestingly, incapacity benefits are also higher than unemployment compensation but only mildly so. Besides being larger than the other forms of social spending, spending on retirement and on health is more uniform than the rest, including unemployment compensation. Health spending is by far the most uniform of all. Taken as a percentage of total government spending, it is 6 times larger than its standard deviation. By contrast, incapacity related cash benefits, unemployment compensation, and government subsidies to firms (relative to total government spending) are on average only around twice as large as their standard deviations. Of these last three rubrics, spending on incapacity benefits is the most uniform. Paid sick leave is the least uniform social spending category of all as well as the smallest. These differences in uniformity persist almost unchanged if we compare the 20 country averages over the study period (either in levels or per capita) and thereby abstract from movements over time. The differences are therefore essentially international. The impression can then arise that if there is any cyclical responsiveness in government spending on health, retirement, incapacity, sickness, unemployment, and government subsidies in the cross-sectional evidence, it would be reflected more clearly in the individual-country estimates for health and retirement than for the other social spending groupings. This impression will turn out to be wrong, as we have already had occasion to mention, since the cyclical sensitivity of these other spending items is more variable internationally than that of unemployment compensation.

\subsection{Estimating the automatic response of the budget surplus}

Let us begin discussing the estimates of equations (1) and (2) without any disaggregation at all, that is with the dependent variable defined as the net government surplus in one case and the ratio of this surplus to output in the other. Table 2, which contains these estimates, omits all coefficients except those for $\Delta\left(\mathrm{Y}-\mathrm{Y}^{*}\right)$ or $\Delta\left(\mathrm{Y} / \mathrm{Y}^{*}\right), \Delta \pi$ and $\mathrm{r}_{\mathrm{L}}$. The table shows two sets of estimates for each specification: those obtained (i) from the least possible sophisticated statistical method of analysis, ordinary least squares, OLS, and ii) from the main statistical method we shall use, three stage least squares, 3SLS. 
Table 2. Aggregate Estimates- Net Government Surplus

\begin{tabular}{|c|c|c|c|c|c|c|}
\hline $\begin{array}{l}20 \text { countries } \\
1982-2001, n=344\end{array}$ & $\begin{array}{l}\text { Levels } \\
\text { OLS }\end{array}$ & & 3SLS & & $\begin{array}{l}\text { Ratios } \\
\text { OLS }\end{array}$ & 3SLS \\
\hline $\begin{array}{l}\text { Change in output gap, } \\
\Delta\left(\mathrm{Y}-\mathrm{Y}^{*}\right) \text { or } \Delta\left(\mathrm{Y} / \mathrm{Y}^{*}\right)\end{array}$ & $\begin{array}{l}0.427 \\
(0.045)\end{array}$ & & $\begin{array}{l}0.404 \\
(0.066)\end{array}$ & & $\begin{array}{l}0.206 \\
(0.058)\end{array}$ & $\begin{array}{l}0.279^{* * *} \\
(0.053)\end{array}$ \\
\hline Change in inflation, $\Delta \pi$ & $\begin{array}{l}\text { n.r. } \\
\text { (n.r.) }\end{array}$ & & $\begin{array}{l}\text { n.r. } \\
\text { (n.r.) }\end{array}$ & $*$ & $\begin{array}{l}0.0020^{* * *} \\
(0.058)\end{array}$ & $\begin{array}{l}0.0001 \\
(0.001)\end{array}$ \\
\hline Long term interest rate, $r_{L}$ & $\begin{array}{l}\text { n.r. } \\
\text { (n.r.) }\end{array}$ & & $\begin{array}{l}\text { n.r. } \\
\text { (n.r.) }\end{array}$ & & $\begin{array}{l}0.0001 \\
(0.0004)\end{array}$ & $\begin{array}{l}0.0005 \\
(0.001)\end{array}$ \\
\hline $\mathrm{R}^{2}$ & 0.56 & & 0.55 & & 0.52 & 0.47 \\
\hline \multicolumn{7}{|c|}{$\begin{array}{l}\text { Notes: Variables are expressed in current prices. Where relevant, estimated coefficients are followed by }{ }^{* * * *}{ }^{* *} \\
\text { and }{ }^{*} \text { to denote statistical significance at } 1,5 \text { and } 10 \% \text { significance levels respectively. Robust standard errors } \\
\text { are reported in parentheses. Where coefficients would be meaningless, we have marked n.r. for not reported. In } \\
\text { case of the } 3 \text { SLS results pseudo } \mathrm{R}^{2} \text { s are reported. In principle, both sets of } 3 \text { SLS estimates should be below the } \\
\text { corresponding OLS ones, since the failure to consider the reciprocal influence of fiscal policy on current } \\
\text { performance in the OLS estimates should lead to overestimation not underestimation of the extent of automatic } \\
\text { fiscal policy. This condition is met in levels not in ratios. To explain the logic, suppose that a cyclical rise in } \\
\text { output raises the net government surplus. In principle, this rise should limit the increase in output. If it does, } \\
\text { then the correction for the reciprocal influence means raising the swings in } \Delta\left(\mathrm{Y}-\mathrm{Y}^{*}\right) \text { above observed levels: } \\
\text { that is, substituting higher positive values of } \Delta\left(\mathrm{Y}-\mathrm{Y}^{*}\right) \text { in expansions and higher negative values of it in } \\
\text { contractions. On the other hand, following the cyclical corrections, the series for the net government surplus } \\
\text { stay the same. Thus, regressing the latter series on the corrected (larger absolute) values for } \Delta\left(\mathrm{Y}-\mathrm{Y}^{*}\right) \text { should } \\
\text { yield lower coefficients. } \\
\text { Source: authors' own calculations. }\end{array}$} \\
\hline
\end{tabular}

The OLS estimate for the impact of the output gap on the net government surplus is .43 , in broad agreement with the literature. The corresponding OLS estimate in ratios is lower at .21. In the case of the 3SLS estimates, the one in levels is .4, somewhat below the 3SLS one, and the one in ratios is higher at 0.28 .

\subsection{Estimating the automatic responses of individual taxes and expenditures}

We turn next to estimates of our full system of 18 equations after the decomposition of the net government surplus into 15 different rubrics. The decomposition rests on the following balance sheet identity in the OECD accounts: net government surplus $=(1)$ direct household taxes $+(2)$ other direct taxes, primarily levied on business $+(3)$ social security taxes $+(4)$ indirect taxes $-(5)$ current (wage and non-wage) spending plus capital spending exclusive of social health expenditures (listed as current spending n.h., or net of health, in the tables) - (6) social health expenditures - (7) other government consumption - (8) pension related cash benefits - (9) social spending on incapacity related cash benefits - (10) social spending on sickness benefits - (11) unemployment compensation - (12) other social expenditures - (13) government subsidies to firms - (14) other government transfer payments - (15) net interest payments. In reporting the results, we shall ignore four of these accounts: the three residual ones, (7), (12) and (14) and net interest (15). Of these, the three residual ones are difficult to interpret and net interest payments are often excluded from the start by focusing on the primary surplus. (Net interest always responds significantly to the output gap with the right negative sign.) In addition, we will base our estimates 
of the aggregate response of the net government surplus on the statistically significant values of the 11 other accounts - or those that we do report - at the .95 confidence level. In this respect, we follow official practice. The official method of calculating total automatic stabilisation is to add up the estimates for the 5 rubrics that are deemed significant from the start. We do the same except that we admit the potential significance of 11 rubrics and only retain those rubrics that prove statistically significant.

Table 3 contains the results. In the interests of legibility and space, we show only the coefficients of $\Delta\left(Y-\mathrm{Y}^{*}\right)$ or $\Delta\left(\mathrm{Y} / \mathrm{Y}^{*}\right)$ and omit those of $\Delta \pi$ and $\mathrm{r}_{\mathrm{L}}$ in this next table. The controls for the reciprocal effects of the dependent variable on $\Delta\left(\mathrm{Y}-\mathrm{Y}^{*}\right)$ or $\Delta\left(\mathrm{Y} / \mathrm{Y}^{*}\right), \Delta \pi$ and $\mathrm{r}_{\mathrm{L}}$ are identical to those employed in the aggregate estimates and are discussed in the appendix. In this case, we also experimented with some additional non-policy variables in order to control for omitted variable bias, including the dependency ratio, the proportion of the population aged 25-54 and the female participation rate, either in levels or first differences. The results with these variables are virtually identical and we ignore them.

Table 3. Disaggregate Estimates- Net Government Surplus

\begin{tabular}{|c|c|c|}
\hline $\begin{array}{l}20 \text { countries } \\
1982-2001, \mathrm{n}=344 \\
\end{array}$ & $\begin{array}{l}\text { Levels } \\
\Delta\left(Y-Y^{*}\right)\end{array}$ & $\begin{array}{l}\text { Ratios } \\
\Delta\left(Y / Y^{*}\right)\end{array}$ \\
\hline \multicolumn{3}{|l|}{ Revenues: } \\
\hline Household Direct Taxes & $\begin{array}{l}0.261^{* * *} \\
(0.020)\end{array}$ & $\begin{array}{l}-0.0503 \\
(0.034)\end{array}$ \\
\hline Other Direct Taxes & $\begin{array}{l}0.144^{* * *} \\
(0.017)\end{array}$ & $\begin{array}{l}-0.001 \\
(0.026)\end{array}$ \\
\hline Social Security Contributions & $\begin{array}{l}0.0367^{* * *} \\
(0.013)\end{array}$ & $\begin{array}{l}-0.0369 \\
(0.025)\end{array}$ \\
\hline Indirect Taxes & $\begin{array}{r}0.0121 \\
(0.014)\end{array}$ & $\begin{array}{l}-0.002 \\
(0.027)\end{array}$ \\
\hline Expenditure: & & \\
\hline Current Spending n.h. & $\begin{array}{l}-0.0164 \\
(0.025)\end{array}$ & $\begin{array}{l}-0.153^{* * *} \\
(0.043)\end{array}$ \\
\hline Health Expenditure & $\begin{array}{l}-0.0409^{* * *} \\
(0.0057)\end{array}$ & $\begin{array}{l}-0.0474^{* * *} \\
(0.011)\end{array}$ \\
\hline Pension Related Cash Benefits & $\begin{array}{l}-0.0424^{* * *} \\
(0.0049)\end{array}$ & $\begin{array}{l}-0.0737^{* * *} \\
(0.013)\end{array}$ \\
\hline Incapacity Related Cash Benefits & $\begin{array}{l}-0.0124^{* * *} \\
(0.0018)\end{array}$ & $\begin{array}{l}-0.019^{* * *} \\
(0.0056)\end{array}$ \\
\hline Unemployment Compensation & $\begin{array}{l}-0.0392^{* * *} \\
(0.0044)\end{array}$ & $\begin{array}{l}-0.0497^{* * *} \\
(0.0093)\end{array}$ \\
\hline Sickness Pay & $\begin{array}{r}0.00012 \\
(0.0026)\end{array}$ & $\begin{array}{l}-0.0077 \\
(0.0063)\end{array}$ \\
\hline Subsidies & $\begin{array}{l}-0.0300^{* * *} \\
(0.0042)\end{array}$ & $\begin{array}{l}-0.0343^{* * * *} \\
(0.012)\end{array}$ \\
\hline
\end{tabular}

Notes: see Table 2. Source: authors' own calculations.

As can be seen, the results are as signaled in the introduction. A positive output gap produces 44 cents more tax collection per dollar in levels. Direct household taxes (constituting .28 of total government revenues) are the most important, business taxes (constituting .07 of the total revenues) are much less but still notably so, social security taxes (.23) far less still and indirect taxes (.29) not at all. On the spending side, government purchases of goods and services do not 
respond to the cycle, but there is 13.5 cents less social spending on persons per dollar of output gap, and pensions, health and unemployment compensation each account for around 4 cents of this total. Incapacity benefits drop by about one cent per dollar of output gap while sickness benefits do not respond significantly at all.

In the case of ratios, taxes contribute nothing to stabilisation: all of the significant contributions come from the spending side. In other words, no category of taxes proves to be either progressive or regressive. On the other hand, government spending on goods and services exclusive of spending on health shows up as highly stabilising. Since this spending does not emerge as significant in levels, the stabilising response in ratios can only be interpreted as coming from inertia or, more generally, a failure of to keep up with the cycle. With regard to social spending, including health, all of the influences that were stabilising in levels remain significantly so. However, now the contribution of social spending on pensions becomes notably more important than either health or unemployment compensation. This spending contributes 7.4 percentage points to stabilisation as opposed to 4.7 for health and 5 for unemployment compensation. In addition, incapacity benefits become somewhat more significant and sick benefits remain insignificant. Based on all of the significant social spending influences, the total contribution of social spending is the single most important factor in automatic stabilisation, accounting for more than half of the total. Total automatic stabilisation from all significant sources is 0.61 in levels and 0.38 in ratios. We shall retain these figures in preference to the earlier ones in Table 2.

Before proceeding, it is interesting to pause once more on the fact, noted in the introduction, that our results for incapacity and sickness benefits contradict a section of the literature claiming that both of these sorts of expenditures move pro-cyclically. As we also observed before, this interpretation is closely connected to the use of the rate of unemployment as the measure of the cycle. Simply in order to shed more light on this pending issue, we substituted the change in the rate of unemployment for $\Delta\left(\mathrm{Y}-\mathrm{Y}^{*}\right)$ or $\Delta\left(\mathrm{Y} / \mathrm{Y}^{*}\right)$ in our 18-equation framework. Concomitantly, we deflated the spending variables by prices, as makes sense if unemployment is treated as an explanatory variable. In this case paid sick leave moves negatively with the rate of unemployment both in levels and ratios, though not significantly so, while incapacity pay moves positively with unemployment in levels and ratios and very significantly so. Thus, the results with respect to sign conform to the conflicting literature regarding sick pay but clearly contradict this literature concerning incapacity pay. ${ }^{5}$

The conformity concerning paid sick leave is statistically weak, as mentioned. But even had it been strong, we would still contest any inference of a pro-cyclical movement in sick pay on the earlier ground that unemployment and sick pay are both jointly determined. We would especially insist on this joint determination in the context of business cycles. Imagine the existence of a negative relationship between unemployment and sick pay for the sort of reasons stressed in the pro-cyclical literature: higher costs of shirking when unemployment is higher in particular.

\footnotetext{
${ }^{5}$ In fact, the contradiction regarding disability pay strictly relates to Boone and van Ours (2002), who find that reported work accidents - not exactly the same thing as disability pay though positively related - rise when unemployment goes down. On the other hand, Khan, Gerdtham and Jansson (2004), who use disability pay and sickness pay as the dependent variables as we do and who expect negative signs in both cases, find the same positive effect of unemployment on disability pay that we get, contrary to their expectations (while they do get the negative sign they expect for sickness pay). Other differences should be mentioned between us and the latter: they estimate in levels rather than first differences, do not correct the nominal variables for prices and add some additional demographic controls that we omit in Table 3 but that we experimented with all the same.
} 
Imagine too that movements in the recorded unemployment rate occur not only for cyclical reasons but also for secular ones related to demography and changes in benefit eligibility criteria and monitoring. During recessions, employers will not only tend to separate themselves from less reliable workers (thus leaving them without any ability to claim sick pay for temporary illness), just as this conflicting literature suggests, but they may also layoff some workers who are ill, or whom they believe to be eligible to claim sick benefits, that the employers wish to retain. This last tendency implies a positive association between sickness pay and unemployment in recessions. In regressions of the change in sickness pay on the change in unemployment, the long run movement in unemployment is a factor and the forces leading to a negative relationship between the two variables (the disciplining effect) might dominate. But in a regression like ours, identifying the cycle with impulses arising from the goods market without any trend (and therefore excluding the long run forces working on unemployment), the positive association between movements in unemployment and sickness pay might dominate instead.

\section{ROBUSTNESS CHECKS AND EXTENSIONS}

In this section we investigate the robustness of our findings in a variety of ways. We check the sensitivity of the results to dropping countries one at a time; investigate behaviour within the EU sub-group in the sample; and examine panel estimates over the sub-samples 1982-1991 and 19922001. We also check the sensitivity of our key results to an alternative measure of the cycle; test the null hypothesis of symmetry of effects against the alternative of asymmetric adjustment of fiscal variables to positive and negative output gaps; and test for non-linear effects of the cycle. Finally, we look at what happens if we retain our exact same specification but employ the Social Expenditure database released by the OECD in 2007, containing data going up to 2003, while keeping the previous data from the Economic Outlook 2005:2 release (which had always permitted going beyond 2001 and even 2003).

\subsection{Do the results depend critically on any single country?}

In order to check whether our results depend critically on any single country, we re-estimated the model 20 times, sequentially dropping one country at a time. This test is the one that led us to remove Japan from the panel estimation in the first place. The problem was not that Japan affected the signs or the significance of the variables, but its presence did notably alter the size of the coefficients. This remained true when we split the sample in half between the eighties and the nineties (or thereabout). Therefore, whatever it is that makes Japan alter the size of the coefficients significantly holds true for both sub-periods. However, we saw no reason on this ground to exclude Japan in our subsequent individual-country tests. The results of the panel estimates dropping one country at a time, following the exclusion of Japan, appear in Tables A1a and A1b of the appendix. All alternative 19-country sub-samples are shown. The table repeats the parameter estimates for the full 20-country sample on the first row to facilitate comparison. It can be seen that both the size and significance of the parameter estimates are relatively insensitive to the 
exclusion of any one country from the sample.

\subsection{Is automatic stabilisation different within the EU?}

Table 4 pursues the previous test by paring down the sample to a sub-sample consisting of the 13 members of the European Union in 2001. Once again we show the results for the full sample in the table to facilitate comparison. There is no systematic difference between the EU results and the full sample ones on the revenue side except for a significant positive effect of the cycle on "other direct taxes" (which primarily consist of business taxes) in ratios in the case of the EU. The differences are more notable on the spending side, though these too are mostly moderate except for health expenditure in levels. However, there is one outlier: the excessively high stabilising figure for current expenditures net of health - in levels, not in ratios. This is the first of a series of less satisfactory results in levels than in ratios that we shall mention. If we abstract from this last figure in levels, the results for the EU broadly agree with those for the full sample.

Table 4. Estimates for the European Union

\begin{tabular}{|c|c|c|c|c|}
\hline \multirow[t]{2}{*}{ 3SLS Estimates, 1982-2001 } & \multicolumn{2}{|c|}{ Levels $\Delta\left(Y-\mathrm{Y}^{*}\right)$} & \multicolumn{2}{|c|}{ Ratios $\Delta\left(\mathrm{Y} / \mathrm{Y}^{*}\right)$} \\
\hline & $\begin{array}{l}\text { All } \\
n=344\end{array}$ & $\begin{array}{l}\mathrm{EU} \\
\mathrm{n}=239\end{array}$ & $\begin{array}{l}\text { All } \\
n=344\end{array}$ & $\begin{array}{l}\mathrm{EU} \\
\mathrm{n}=239\end{array}$ \\
\hline \multicolumn{5}{|l|}{ Revenues: } \\
\hline $\begin{array}{l}\text { Revenues: } \\
\text { Household Direct Taxes }\end{array}$ & $\begin{array}{l}0.261^{* * *} \\
(0.020)\end{array}$ & $\begin{array}{l}0.269^{* * *} \\
(0.035)\end{array}$ & $\begin{array}{l}-0.0503 \\
(0.034)\end{array}$ & $\begin{array}{l}-0.0147 \\
(0.042)\end{array}$ \\
\hline Other Direct Taxes & $\begin{array}{l}0.144^{* * *} \\
(0.017)\end{array}$ & $\begin{array}{l}0.128^{* * *} \\
(0.031)\end{array}$ & $\begin{array}{l}-0.001 \\
(0.026)\end{array}$ & $0^{0.0760^{* * *}}{ }^{* 0.029)}$ \\
\hline Social Security Contributions & $\begin{array}{l}0.0367^{* * *} \\
(0.013)\end{array}$ & $\begin{array}{c}0.0844^{*} \\
(0.046)\end{array}$ & $\begin{array}{c}-0.0369 \\
(0.025)\end{array}$ & $\begin{array}{l}-0.00494 \\
(0.034)\end{array}$ \\
\hline Indirect Taxes & $\begin{array}{r}0.0121 \\
(0.014)\end{array}$ & $\begin{array}{l}-0.0284 \\
(0.047)\end{array}$ & $\begin{array}{l}-0.002 \\
(0.027)\end{array}$ & $\begin{array}{l}-0.0406 \\
(0.032)\end{array}$ \\
\hline \multicolumn{5}{|l|}{ Expenditure: } \\
\hline Current Spending n.h. & $\begin{array}{l}-0.0164 \\
(0.025)\end{array}$ & $\begin{array}{l}-0.428^{* * *} \\
(0.068)\end{array}$ & $\begin{array}{l}-0.153^{* * *} \\
(0.043)\end{array}$ & $\begin{array}{l}-0.152^{* * *} \\
(0.054)\end{array}$ \\
\hline Health Expenditure & $\begin{array}{l}-0.0409^{* * *} \\
(0.0057)\end{array}$ & $\begin{array}{l}0.00420 \\
(0.013)\end{array}$ & $\begin{array}{l}-0.0474^{* * *} \\
(0.011)\end{array}$ & $\begin{array}{l}-0.0522^{* * *} \\
(0.014)\end{array}$ \\
\hline Pension Related Cash Benefits & $\begin{array}{l}-0.0424^{* * *} \\
(0.0049)\end{array}$ & $\begin{array}{l}-0.0730^{* * *} \\
(0.013)\end{array}$ & $\begin{array}{l}-0.0737^{* * *} \\
(0.013)\end{array}$ & $\begin{array}{l}-0.0826^{* * *} \\
(0.016)\end{array}$ \\
\hline Incapacity Related Cash Benefits & $\begin{array}{l}-0.0124^{* * *} \\
(0.0018)\end{array}$ & $\begin{array}{l}-0.0431^{* * *} \\
(0.0051)\end{array}$ & $\begin{array}{l}-0.019^{* * *} \\
(0.0056)\end{array}$ & $\begin{array}{l}-0.0178^{* *} \\
(0.0072)\end{array}$ \\
\hline Unemployment Compensation & $\begin{array}{l}-0.0392^{* * *} \\
(0.0044)\end{array}$ & $\begin{array}{l}-0.0404^{* * *} \\
(0.011)\end{array}$ & $\begin{array}{l}-0.0497^{* * * *} \\
(0.0093)\end{array}$ & $\begin{array}{l}-0.0662^{* * *} \\
(0.011)\end{array}$ \\
\hline Sickness Pay & $\begin{array}{c}0.00012 \\
(0.0026)\end{array}$ & $\begin{array}{l}0.00967 \\
(0.011)\end{array}$ & $\begin{array}{l}-0.0077 \\
(0.0063)\end{array}$ & $\begin{array}{l}-0.0202^{* *} \\
(0.0088)\end{array}$ \\
\hline Subsidies & $\begin{array}{l}-0.0300^{* * *} \\
(0.0042)\end{array}$ & $\begin{array}{l}-0.0985^{* * *} \\
(0.012)\end{array}$ & $\begin{array}{l}-0.0343^{* * *} \\
(0.012)\end{array}$ & $\begin{array}{l}-0.0618^{* * *} \\
(0.016)\end{array}$ \\
\hline
\end{tabular}

Notes: see Table 2. Source: authors' own calculations.

\subsection{Have contributions to automatic stabilisation changed over time?}

To investigate the possibility that the contributions of the various components of automatic stabilisation have changed over time we conducted split sample estimates for 1982-1991 and for 
Table 5. Split Sample Estimates for 1982-1991 and 1992-2001

\begin{tabular}{|c|c|c|c|c|c|c|}
\hline \multirow[t]{2}{*}{ 3SLS Estimates, 1982-2001 } & \multicolumn{2}{|c|}{ Levels $\Delta\left(\mathrm{Y}-\mathrm{Y}^{*}\right)$} & \multirow[b]{2}{*}{$\begin{array}{l}\begin{array}{l}1997- \\
n=199\end{array} \\
n\end{array}$} & \multicolumn{2}{|c|}{ Ratios $\Delta\left(\mathrm{Y} / \mathrm{Y}^{*}\right)$} & \multirow[b]{2}{*}{$\begin{array}{l}1997- \\
n=199\end{array}$} \\
\hline & $\begin{array}{l}\text { All } \\
\mathrm{n}=344\end{array}$ & $\begin{array}{l}1982-91 \\
\mathrm{n}=145\end{array}$ & & $\begin{array}{l}\text { All } \\
\mathrm{n}=344\end{array}$ & $\begin{array}{l}1982-91 \\
\mathrm{n}=145\end{array}$ & \\
\hline \multicolumn{7}{|l|}{ Revenues: } \\
\hline Household Direct Taxes & $\begin{array}{l}0.261^{* * *} \\
(0.02)\end{array}$ & $\begin{array}{l}0.105^{* * *} \\
(0.024)\end{array}$ & $\begin{array}{l}0.305^{* * *} \\
(0.023)\end{array}$ & $\begin{array}{l}-0.0503 \\
(0.034)\end{array}$ & $\begin{array}{l}-0.0782 \\
(0.049)\end{array}$ & $\begin{array}{r}0.0324 \\
(0.041)\end{array}$ \\
\hline Other Direct Taxes & $\begin{array}{l}0.144^{* * *} \\
(0.017)\end{array}$ & $\begin{array}{l}0.125^{* * *} \\
(0.010)\end{array}$ & $(0.023)$ & $\begin{array}{l}-0.000961 \\
(0.026)\end{array}$ & $\begin{array}{l}-0.0355 \\
(0.024)\end{array}$ & $\begin{array}{l}-0.0170 \\
(0.04)\end{array}$ \\
\hline Social Security Contributions & $\begin{array}{l}0.0367^{* * *} \\
(0.013)\end{array}$ & $\begin{array}{l}0.0557^{* * *} \\
(0.0098)\end{array}$ & $\begin{array}{r}0.0332 \\
(0.020)\end{array}$ & $\begin{array}{l}-0.0369 \\
(0.025)\end{array}$ & $\begin{array}{r}0.0063 \\
(0.032)\end{array}$ & $\begin{array}{l}-0.0555^{*} \\
(0.034)\end{array}$ \\
\hline Indirect Taxes & $\begin{array}{r}0.0121 \\
(0.014)\end{array}$ & $\begin{array}{l}0.0415^{* * *} \\
(0.012)\end{array}$ & $\begin{array}{c}0.0333^{*} \\
(0.019)\end{array}$ & $\begin{array}{l}-0.00196 \\
(0.027)\end{array}$ & $\begin{array}{l}-0.0139 \\
(0.029)\end{array}$ & $\begin{array}{l}-0.0103 \\
(0.039)\end{array}$ \\
\hline Expenditure: & & & & & & \\
\hline Current Spending n.h. & $\begin{array}{l}-0.0164 \\
(0.025)\end{array}$ & $\begin{array}{l}0.0489^{* * *} \\
(0.019)\end{array}$ & $\begin{array}{l}-0.103^{* *} \\
(0.04)\end{array}$ & $\begin{array}{l}-0.153^{* * *} \\
(0.043)\end{array}$ & $\begin{array}{l}-0.125^{* *} \\
(0.053)\end{array}$ & $\begin{array}{l}-0.213^{* * *} \\
(0.056)\end{array}$ \\
\hline Health Expenditure & $\begin{array}{l}-0.0409^{* * *} \\
(0.0057)\end{array}$ & $\begin{array}{l}-0.0215^{* * *} \\
(0.0057)\end{array}$ & $\begin{array}{l}-0.0527^{* * *} \\
(0.0087)\end{array}$ & $\begin{array}{l}-0.0474^{* * *} \\
(0.011)\end{array}$ & $\begin{array}{l}-0.0124 \\
(0.016)\end{array}$ & $\begin{array}{l}-0.0664^{* * *} \\
(0.014)\end{array}$ \\
\hline Pension Related Cash Benefits & $\begin{array}{l}-0.0424^{* * *} \\
(0.0049)\end{array}$ & $\begin{array}{l}-0.0391^{* * *} \\
(0.0046)\end{array}$ & $\begin{array}{l}-0.0402^{* * *} \\
(0.0066)\end{array}$ & $\begin{array}{l}-0.0737^{* * *} \\
(0.013)\end{array}$ & $\begin{array}{l}-0.0578^{* * *} \\
(0.017)\end{array}$ & $\begin{array}{l}-0.102^{* * *} \\
(0.019)\end{array}$ \\
\hline Incapacity Related Cash Benefits & $\begin{array}{l}-0.0124^{* * *} \\
(0.0018)\end{array}$ & $\begin{array}{l}-0.00224 \\
(0.0014)\end{array}$ & $\begin{array}{l}-0.0211^{* * *} \\
(0.0024)\end{array}$ & $\begin{array}{l}-0.019^{* * *} \\
(0.0056)\end{array}$ & $\begin{array}{l}-0.0007 \\
(0.0075)\end{array}$ & $\begin{array}{l}-0.0228^{* * *} \\
(0.0069)\end{array}$ \\
\hline Unemployment Compensation & $\begin{array}{l}-0.0392^{* * *} \\
(0.0044)\end{array}$ & $\begin{array}{l}-0.032^{* * *} \\
(0.0053)\end{array}$ & $\begin{array}{l}-0.0283^{* * *} \\
(0.0053)\end{array}$ & $\begin{array}{l}-0.0497^{* * *} \\
(0.0093)\end{array}$ & $\begin{array}{l}-0.0536^{* * *} \\
(0.013)\end{array}$ & $\begin{array}{l}-0.0694^{* * *} \\
(0.011)\end{array}$ \\
\hline Sickness Pay & $\begin{array}{l}-0.000122 \\
(0.0026)\end{array}$ & $\begin{array}{l}-0.000206 \\
(0.0034)\end{array}$ & $\begin{array}{l}0.00227 \\
(0.0029)\end{array}$ & $\begin{array}{l}-0.00769 \\
(0.0063)\end{array}$ & $\begin{array}{l}-0.0067 \\
(0.0093)\end{array}$ & $\begin{array}{l}-0.0159^{* * *} \\
(0.0058)\end{array}$ \\
\hline Subsidies & $\begin{array}{l}-0.0300^{* * *} \\
(0.0042)\end{array}$ & $\begin{array}{l}-0.0110^{* * *} \\
(0.0040)\end{array}$ & $\begin{array}{l}-0.0352^{* * *} \\
(0.0056)\end{array}$ & $\begin{array}{l}-0.0343^{* * *} \\
(0.012)\end{array}$ & $\begin{array}{l}-0.0234 \\
(0.016)\end{array}$ & $\begin{array}{l}-0.00725 \\
(0.015)\end{array}$ \\
\hline
\end{tabular}

Notes: see Table 2. Source: authors' own calculations. 
1992-2001. There are fewer observations available for the earlier period than the later one: 145 rather than 199. In fact, some countries even fall out entirely from the 1982-1991 sub-sample. Unfortunately, this means that apparent differences over time could reflect simply changes in the country composition across the two sub-samples. To control for this possibility, we also conducted estimates based on a dataset including only those 11 countries for which data is available throughout the 1982-2001 period (Australia, Austria, Canada, Denmark, Finland, France, the Netherlands, New Zealand, Sweden, Switzerland and the US). This limited us to about two-thirds of the observations. Of course, with so much loss of data, the resulting estimates are less precise, and this lower precision is reflected in larger standard errors. Therefore, we shall only use the panel data estimates from the smaller set of countries (which we do not report) to throw light on whether the split sample results in Table 5 truly reflect changes in automatic stabilising behaviour over time rather than mere changes in the country composition of the sub-samples.

According to the levels results in Table 5, direct taxes appear to become much more stabilising in the nineties. In addition, indirect taxes emerge as mildly stabilising in each sub-period even though these taxes had not appeared so in the full sample. The change in direct taxes is strongly confirmed in the 11 country dataset and thus evidently reflects a genuine change over time. In the case of ratios, the previous changes do not appear significant. Instead, the results on the revenue side reveal some counter-cyclical movement in social security contributions after the eighties (that had not shown up in the full sample). As regards spending, health expenditures and incapacity benefits become clearly more stabilising both in levels and ratios in the more recent period and pensions do so though only in ratios. In the case of incapacity benefits, the earlier stabilising behaviour we had found seems to have begun in the nineties. There is also some evidence of stabilising behaviour of sickness benefits since the nineties but only in ratios. The comparison with the 11-country dataset gives little reason to doubt that all of these changes on the spending side reflect genuine movements over time. By contrast, the stabilising behaviour of unemployment compensation remains essentially the same during the sample period. The contrast between the steady stabilising behaviour of unemployment compensation throughout the period and the much higher significance of automatic stabilisation by the rest of social spending in the second half could help explain why in our subsequent study of individual countries, where data is notably scarcer, the significance of unemployment compensation emerges more plainly than the rest.

\subsection{Does the measure of the cycle matter?}

In an additional experiment we replaced the OECD measure of the output gap with one obtained from HP filtered data. This only affects the dating of the cycles marginally although it does modify the steepness and the depth of the cycles. As can be seen from Table 6, the results are generally very similar to those with the OECD measure in the case of ratios; but the differences in levels are important. This is another of a number of signs we have had throughout the study that the econometric results obtained in ratios are more robust than those obtained in levels. In the case of levels, the most general difference in the event of the HP-filtered measure of the gap is that the stabilising influence of receipts appears much smaller relative to that of expenditures. The stabilising influence of receipts even disappears on the whole. While this supports our general 
emphasis on expenditures, we have a basic preference for the results with the OECD measure of the output gap based on our earlier experiments with both measures as well as similar ones by the OECD.

Table 6. Alternative measures of the output gap

\begin{tabular}{|c|c|c|c|c|}
\hline \multirow{2}{*}{$\begin{array}{l}\text { 3SLS Estimates, 1982-2001 } \\
\mathrm{n}=344\end{array}$} & \multicolumn{2}{|c|}{ Levels $\Delta\left(\mathrm{Y}-\mathrm{Y}^{*}\right)$} & \multicolumn{2}{|c|}{ Ratios $\Delta\left(\mathrm{Y} / \mathrm{Y}^{*}\right)$} \\
\hline & OECD gap & HP gap & OECD gap & HP gap \\
\hline \\
\hline Household Direct Taxes & $\begin{array}{l}0.261^{* * *} \\
(0.020)\end{array}$ & $\begin{array}{l}0.0272^{*} \\
(0.014)\end{array}$ & $\begin{array}{l}-0.0503 \\
(0.034)\end{array}$ & $\begin{array}{l}-0.0375 \\
(0.033)\end{array}$ \\
\hline \multirow[t]{2}{*}{ Other Direct Taxes } & $0.144^{* * *}$ & -0.0039 & -0.001 & 0.0038 \\
\hline & $(0.017)_{* * * *}$ & $(0.017)$ & $(0.026)$ & $(0.027)$ \\
\hline Social Security Contributions & $\begin{array}{l}0.0367^{* * *} \\
(0.013)\end{array}$ & $\begin{array}{r}0.0077 \\
(0.015)\end{array}$ & $\begin{array}{l}-0.0369 \\
(0.025)\end{array}$ & $\begin{array}{l}-0.0660^{* * *} \\
(0.025)\end{array}$ \\
\hline Indirect Taxes & $\begin{array}{r}0.0121 \\
(0.014)\end{array}$ & $\begin{array}{r}0.0261 \\
(0.016)\end{array}$ & $\begin{array}{l}-0.002 \\
(0.027)\end{array}$ & $\begin{array}{l}-0.0322 \\
(0.028)\end{array}$ \\
\hline \multicolumn{5}{|l|}{ Expenditure: } \\
\hline Current Spending n.h. & $\begin{array}{l}-0.0164 \\
(0.025)\end{array}$ & $\begin{array}{l}-0.103^{* * *} \\
(0.024)\end{array}$ & $\begin{array}{l}-0.153^{* * *} \\
(0.043)\end{array}$ & $\begin{array}{l}-0.168^{* * *} \\
(0.044)\end{array}$ \\
\hline Health Expenditure & $\begin{array}{l}-0.0409^{* * *} \\
(0.0057)\end{array}$ & $\begin{array}{l}-0.0015 \\
(0.0048)\end{array}$ & $\begin{array}{l}-0.0474^{* * *} \\
(0.011)\end{array}$ & $\begin{array}{l}-0.0336^{* * *} \\
(0.012)\end{array}$ \\
\hline Pension Related Cash Benefits & $\begin{array}{l}-0.0424^{* * *} \\
(0.0049)\end{array}$ & $\begin{array}{l}-0.0075 \\
(0.0051)\end{array}$ & $\begin{array}{l}-0.0737^{* * *} \\
(0.013)\end{array}$ & $\begin{array}{l}-0.0750^{* * *} \\
(0.014)\end{array}$ \\
\hline Incapacity Related Cash Benefits & $\begin{array}{l}-0.0124^{* * *} \\
(0.0018)\end{array}$ & $\begin{array}{l}-0.0073^{* * *} \\
(0.0019)\end{array}$ & $\begin{array}{l}-0.019^{* * * *} \\
(0.0056)\end{array}$ & $\begin{array}{l}-0.0291^{* * *} \\
(0.0058)\end{array}$ \\
\hline Unemployment Compensation & $\begin{array}{l}-0.0392^{* * *} \\
(0.0044)\end{array}$ & $\begin{array}{l}-0.0081^{* *} \\
(0.0038)\end{array}$ & $\begin{array}{l}-0.0497^{* * *} \\
(0.0093)\end{array}$ & $\begin{array}{l}-0.0518^{* * *} \\
(0.0094)\end{array}$ \\
\hline Sickness Pay & $\begin{array}{r}0.00012 \\
(0.0026)\end{array}$ & $\begin{array}{c}0.0057^{*} \\
(0.0031)\end{array}$ & $\begin{array}{l}-0.0077 \\
(0.0063)\end{array}$ & $\begin{array}{l}-0.0049 \\
(0.0064)\end{array}$ \\
\hline Subsidies & $\begin{array}{l}-0.0300^{* * *} \\
(0.0042)\end{array}$ & $\begin{array}{l}-0.0092^{* *} \\
(0.0043)\end{array}$ & $\begin{array}{l}-0.0343^{* * *} \\
(0.012)\end{array}$ & $\begin{array}{l}-0.0352^{* * *} \\
(0.012)\end{array}$ \\
\hline
\end{tabular}

Notes: see Table 2. Source: authors' own calculations.

\subsection{Is stabilisation symmetric across expansions and contractions?}

Is it possible that the automatic stabilising movements in expenditure and revenues occur to different degrees in contractions and expansions? If so, progressive movements of individual components of the government budget in one direction could affect the net budget surplus and the government debt as a whole over a series of cycles. Such asymmetries are then important. We test for such asymmetries with a dummy variable that takes the value 1 when output is below potential $\left(\mathrm{Y}<\mathrm{Y}^{*}\right)$ and 0 otherwise. By taking the product of this dummy and the change in the output gap and introducing the product term as a separate explanatory variable, we can test for the significance of differences in responses to the cycle when output is below potential. Table 7 shows the outcomes. While a number of significant asymmetries emerge in levels, none persist in ratios. We shall then consider none of these asymmetries as adequately confirmed. 
Table 7. Testing for symmetry versus asymmetry in cyclical responses

\begin{tabular}{|c|c|c|c|c|}
\hline \multirow[t]{2}{*}{ 3SLS Estimates, 1982-2001 } & \multicolumn{2}{|l|}{ Levels } & \multicolumn{2}{|l|}{ Ratios } \\
\hline & $\Delta\left(\mathrm{Y}-\mathrm{Y}^{*}\right)$ & $\begin{array}{l}\text { additional } \\
\text { impact } \\
\text { when } \mathrm{Y}<\mathrm{Y}^{*}\end{array}$ & $\Delta\left(\mathrm{Y} / \mathrm{Y}^{*}\right)$ & $\begin{array}{l}\text { additional } \\
\text { impact } \\
\text { when } \mathrm{Y}<\mathrm{Y}^{*}\end{array}$ \\
\hline Revenues: & & & & \\
\hline Household Direct Taxes & $\begin{array}{l}0.349^{* * *} \\
(0.045)\end{array}$ & $\begin{array}{l}-0.152^{* * *} \\
(0.057)\end{array}$ & $\begin{array}{l}-0.0332 \\
(0.033)\end{array}$ & $\begin{array}{l}-0.0004 \\
(0.0008)\end{array}$ \\
\hline Other Direct Taxes & $\begin{array}{l}0.187^{* * *} \\
(0.038)\end{array}$ & $\begin{array}{l}-0.0747 \\
(0.049)\end{array}$ & $\begin{array}{r}0.0327 \\
(0.026)\end{array}$ & $\begin{array}{l}-0.0003 \\
(0.0007)\end{array}$ \\
\hline Social Security Contributions & $\begin{array}{r}0.0001 \\
(0.031)\end{array}$ & $\begin{array}{r}0.0403 \\
(0.039)\end{array}$ & $\begin{array}{l}-0.0265 \\
(0.024)\end{array}$ & $\begin{array}{c}0.0010 \\
(0.0006)\end{array}$ \\
\hline Indirect Taxes & $\begin{array}{l}-0.046 \\
(0.033)\end{array}$ & $\begin{array}{l}0.0966^{* *} \\
(0.042)\end{array}$ & $\begin{array}{r}0.0291 \\
(0.027)\end{array}$ & $\begin{array}{c}0.0004 \\
(0.0007)\end{array}$ \\
\hline Expenditure: & & & & \\
\hline Current Spending n.h. & $\begin{array}{r}0.0545 \\
(0.058)\end{array}$ & $\begin{array}{l}-0.0868 \\
(0.074)\end{array}$ & $\begin{array}{l}-0.137^{* * *} \\
(0.041)\end{array}$ & $\begin{array}{c}0.0007 \\
(0.0011)\end{array}$ \\
\hline Health Expenditure & $\begin{array}{l}-0.0644^{* * *} \\
(0.013)\end{array}$ & $\begin{array}{l}0.0450^{* * *} \\
(0.016)\end{array}$ & $\begin{array}{l}-0.0349^{* * *} \\
(0.011)\end{array}$ & $\begin{array}{c}0.0003 \\
(0.0003)\end{array}$ \\
\hline Pension Related Cash Benefits & $\begin{array}{l}-0.0349^{* * *} \\
(0.011)\end{array}$ & $\begin{array}{l}-0.0049 \\
(0.014)\end{array}$ & $\begin{array}{l}-0.0701^{* * *} \\
(0.013)\end{array}$ & $\begin{array}{c}0.0006 \\
(0.0003)\end{array}$ \\
\hline Incapacity Related Cash Benefits & $\begin{array}{l}-0.0151^{* * *} \\
(0.004)\end{array}$ & $\begin{array}{c}0.0057 \\
(0.006)\end{array}$ & $\begin{array}{l}-0.0205^{* * *} \\
(0.006)^{* * *}\end{array}$ & $\begin{array}{l}-0.0001 \\
(0.0001)\end{array}$ \\
\hline Unemployment Compensation & $\begin{array}{l}-0.0158 \\
(0.010)\end{array}$ & $\begin{array}{l}-0.0278^{* *} \\
(0.013)\end{array}$ & $\begin{array}{l}-0.0527^{* * *} \\
(0.009)\end{array}$ & $\begin{array}{l}-0.0002 \\
(0.0002)\end{array}$ \\
\hline Sickness Pay & $\begin{array}{l}-0.0031 \\
(0.061)\end{array}$ & $\begin{array}{r}0.0090 \\
(0.008)\end{array}$ & $\begin{array}{l}-0.0001 \\
(0.006)\end{array}$ & $\begin{array}{c}0.0001 \\
(0.0002)\end{array}$ \\
\hline Subsidies & $\begin{array}{l}-0.0133 \\
(0.0099)\end{array}$ & $\begin{array}{l}-0.0208^{*} \\
(0.013)\end{array}$ & $\begin{array}{l}-0.0277^{* *} \\
(0.012) \\
\end{array}$ & $\begin{array}{l}-0.0000 \\
(0.0003) \\
\end{array}$ \\
\hline
\end{tabular}

\subsection{Testing for non-linear effects}

The next set of tests concerned the possible non-linearity of the responses. We tested for this nonlinearity by adding squared values of $\Delta\left(\mathrm{Y}-\mathrm{Y}^{*}\right)$ or $\Delta\left(\mathrm{Y} / \mathrm{Y}^{*}\right)$ to the standard specification. (It was necessary to assign the same signs to the squared terms as those of the initial values.) The results, in Table 8, identify some significant non-linearities in the stabilising influence of a number of the variables in levels. But only one of these persists in ratios: the one concerning health expenditure. This is then the only non-linearity that we shall consider to be adequately confirmed. The interpretation of this non-linearity is that the stabilising effect of health expenditures lessens as the size of health expenditure goes up.

\subsection{Extension of the study period}

Our last robustness test repeats the estimation of our basic 18-equation model using the OECD's 2007 release of internationally coherent data for social expenditure (which contains a small number of back revisions of the social data). This permits us to extend the estimation period by two more years to 2003. Table 9 shows the results. As can be seen, there are only two changes of note to be reported. In the case of levels, direct taxes on households respond more to the cycle. However, this is not true in ratios, where the response remains as insignificant as before. Sickness 
pay also responds significantly and in a stabilising manner both in levels and in ratios though only to a small extent. Otherwise, the responses are quite similar.

Table 8. Testing Non-Linearity

\begin{tabular}{|c|c|c|c|c|}
\hline \multirow[t]{2}{*}{ 3SLS Estimates, 1982-2001 } & \multicolumn{2}{|l|}{ Levels } & \multicolumn{2}{|l|}{ Ratios } \\
\hline & $\Delta\left(\mathrm{Y}-\mathrm{Y}^{*}\right)$ & $\begin{array}{l}\text { sign } \\
\text { preserving } \\
\text { square }\end{array}$ & $\Delta\left(\mathrm{Y} / \mathrm{Y}^{*}\right)$ & $\begin{array}{l}\text { sign } \\
\text { preserving } \\
\text { square }\end{array}$ \\
\hline Revenues: & & & & \\
\hline Household Direct Taxes & $\begin{array}{l}0.345^{* * *} \\
(0.027)\end{array}$ & $\begin{array}{l}-0.152^{* * *} \\
(0.057)\end{array}$ & $\begin{array}{l}-0.0707 \\
(0.042)\end{array}$ & $\begin{array}{l}-0.0052 \\
(0.0059)\end{array}$ \\
\hline Other Direct Taxes & $\begin{array}{l}0.166^{* * *} \\
(0.024)\end{array}$ & $\begin{array}{l}-0.0747 \\
(0.049)\end{array}$ & $\begin{array}{l}-0.0286 \\
(0.042)\end{array}$ & $\begin{array}{l}-0.0038 \\
(0.0048)\end{array}$ \\
\hline Social Security Contributions & $\begin{array}{r}0.0205 \\
(0.019)\end{array}$ & $\begin{array}{r}0.0403 \\
(0.039)\end{array}$ & $\begin{array}{l}-0.0844^{* *} \\
(0.039)\end{array}$ & $\begin{array}{c}0.0077^{* *} \\
(0.0045)\end{array}$ \\
\hline Indirect Taxes & $\begin{array}{l}-0.0314 \\
(0.020)\end{array}$ & $\begin{array}{l}0.0966^{* *} \\
(0.042)\end{array}$ & $\begin{array}{r}0.0369 \\
(0.043)\end{array}$ & $\begin{array}{c}0.0062 \\
(0.0051)\end{array}$ \\
\hline Expenditure: & & & & \\
\hline Current Spending n.h. & $\begin{array}{r}0.0185 \\
(0.037)\end{array}$ & $\begin{array}{c}0.0013 \\
(0.0075)\end{array}$ & $\begin{array}{l}-0.186^{* * *} \\
(0.067)\end{array}$ & $\begin{array}{c}0.0063 \\
(0.0076)\end{array}$ \\
\hline Health Expenditure & $\begin{array}{l}-0.0796^{* * *} \\
(0.0083)\end{array}$ & $\begin{array}{l}0.0100^{* * * *} \\
(0.0016)\end{array}$ & $\begin{array}{l}-0.0809^{* * *} \\
(0.018)\end{array}$ & $\begin{array}{l}0.0052^{* * *} \\
(0.0025)\end{array}$ \\
\hline Pension Related Cash Benefits & $\begin{array}{l}-0.0374^{* * *} \\
(0.0069)\end{array}$ & $\begin{array}{l}-0.0008 \\
(0.0014)\end{array}$ & $\begin{array}{l}-0.103^{* * *} \\
(0.021)\end{array}$ & $\begin{array}{c}0.0043^{*} \\
(0.0025)\end{array}$ \\
\hline Incapacity Related Cash Benefits & $\begin{array}{l}-0.0141^{* * *} \\
(0.0027)\end{array}$ & $\begin{array}{l}0.0005 \\
(0.0006)\end{array}$ & $\begin{array}{l}-0.0185^{* *} \\
(0.0088)\end{array}$ & $\begin{array}{l}-0.00003 \\
(0.0010)\end{array}$ \\
\hline Unemployment Compensation & $\begin{array}{l}-0.0468^{* * *} \\
(0.0063)\end{array}$ & $\begin{array}{c}0.0029^{* *} \\
(0.0013)\end{array}$ & $\begin{array}{l}-0.0479^{* * *} \\
(0.014)\end{array}$ & $\begin{array}{l}-0.0005 \\
(0.0016)\end{array}$ \\
\hline Sickness Pay & $\begin{array}{l}-0.0001 \\
(0.0038)\end{array}$ & $\begin{array}{r}0.00001 \\
(0.0008)\end{array}$ & $\begin{array}{l}-0.0255^{* *} \\
(0.010)\end{array}$ & $\begin{array}{l}0.0031^{* * *} \\
(0.0011)\end{array}$ \\
\hline Subsidies & $\begin{array}{l}-0.0391^{* * *} \\
(0.0061)\end{array}$ & $\begin{array}{c}0.0032^{* *} \\
(0.0013)\end{array}$ & $\begin{array}{l}-0.0094^{* *} \\
(0.019)\end{array}$ & $\begin{array}{l}-0.0037^{*} \\
(0.0022)\end{array}$ \\
\hline
\end{tabular}

Notes: see Table 2. Source: authors' own calculations.

\section{INDIVIDUAL COUNTRY ESTIMATES}

Of course, individual country tests are important. In deciding on policy actions, national authorities must rely on estimates of automatic stabilisation at home and can only use panel results covering 19 other countries to shed additional light on such estimates. As regards individual country estimates, with a maximum of a mere 20 time series observations per country, our basic system of simultaneous estimation is no longer feasible. There are simply too few observations available to use estimation methods admitting simultaneity, and in practice the theoretical gain from greater consistency would not compensate for the loss of precision of the estimates. Consequently, in generating single country results we will stick to the simplest method of estimation, ordinary least squares, while recognising that the estimates may be subject to a degree of simultaneity bias. Even so, we limit estimation to those countries for which a minimum of 15 observations are available. Five countries then fall out (Austria, Iceland, New Zealand, Norway and Switzerland), leaving 16 countries, including Japan. In discussing the results, we shall focus exclusively on the issue of the impact of the different components of social spending on automatic stabilisation. For this reason, we show only the results for social benefits paid to households in Table 10 
Table 9. Checking results remain robust to 2007 release of Social Expenditure Data

\begin{tabular}{|c|c|c|c|c|c|c|}
\hline \multirow[t]{3}{*}{ 3SLS Estimates } & \multicolumn{3}{|c|}{ Levels $\Delta\left(Y-Y^{*}\right)$} & \multicolumn{3}{|c|}{ Ratios $\Delta\left(Y / Y^{*}\right)$} \\
\hline & \multirow{2}{*}{$\begin{array}{l}\text { Original } \\
1982-2001 \\
\mathrm{n}=344\end{array}$} & \multicolumn{2}{|c|}{ New Social Expenditure Data } & \multirow{2}{*}{$\begin{array}{l}\text { Original } \\
1982-2001 \\
\mathrm{n}=344\end{array}$} & \multicolumn{2}{|c|}{ New Social Expenditure Dat } \\
\hline & & $\begin{array}{l}1982-2001 \\
n=350\end{array}$ & $\begin{array}{l}1982-2003 \\
\mathrm{n}=390\end{array}$ & & $\begin{array}{l}1982-2001 \\
n=350\end{array}$ & $\begin{array}{l}1982-2001 \\
n=344\end{array}$ \\
\hline \multicolumn{7}{|l|}{ Revenues: } \\
\hline Household Direct Taxes & $0.261^{* * *}$ & $0.277^{* * *}$ & $0.416^{* * *}$ & -0.0503 & -0.0324 & -0.0353 \\
\hline \multirow{2}{*}{ Other Direct Taxes } & $0.144^{* * *}$ & $0.140^{* * * *}$ & $(0.033)$ & $\begin{array}{l}(0.034) \\
-0.000961\end{array}$ & $\begin{array}{r}(0.034) \\
0.0262\end{array}$ & $(0.034)$ \\
\hline & $(0.017)$ & $(0.017)$ & $(0.018)$ & $(0.026)$ & $(0.026)$ & $(0.026)$ \\
\hline \multirow{2}{*}{ Social Security Contributions } & $0.0367^{* * *}$ & 0.021 & $0.0305^{* *}$ & -0.0369 & -0.0348 & $-0.0432^{*}$ \\
\hline & $(0.013)$ & $(0.013)$ & $(0.013)$ & $(0.025)$ & $(0.025)$ & $(0.024)$ \\
\hline \multirow[t]{2}{*}{ Indirect Taxes } & 0.0121 & 0.0112 & 0.00396 & -0.00196 & -0.0277 & -0.0330 \\
\hline & $(0.014)$ & $(0.014)$ & $(0.014)$ & $(0.027)$ & $(0.027)$ & $(0.026)$ \\
\hline \multicolumn{7}{|l|}{ Expenditure: } \\
\hline \multirow[t]{2}{*}{ Current Spending n.h. } & -0.0164 & -0.0188 & -0.0276 & $-0.153^{* * *}$ & $-0.122^{* * *}$ & $-0.107^{* * *}$ \\
\hline & $(0.025)$ & $(0.025)$ & $(0.026)$ & $(0.043)$ & $(0.042)$ & $(0.041)$ \\
\hline \multirow[t]{2}{*}{ Health Expenditure } & $-0.0409^{* * *}$ & $-0.0466^{* * *}$ & $-0.0523^{* * *}$ & $-0.0474^{* * *}$ & $-0.0700^{* * *}$ & $-0.0678^{* * *}$ \\
\hline & $(0.0057)$ & $(0.0067)$ & $(0.0065)$ & $(0.011)$ & $(0.012)$ & $(0.012)$ \\
\hline \multirow[t]{2}{*}{ Pension Related Cash Benefits } & $-0.0424^{* * * *}$ & $-0.0380^{* * * *}$ & $-0.0395^{* * *}$ & $-0.0737^{* * *}$ & $-0.102^{* * *}$ & $-0.0970^{* * *}$ \\
\hline & $(0.0049)$ & $(0.0058)$ & $(0.0059)$ & $(0.013)$ & $(0.018)$ & $(0.017)$ \\
\hline \multirow[t]{2}{*}{ Incapacity Related Cash Benefits } & $-0.0124^{* * *}$ & $-0.0113^{* * *}$ & $-0.0127^{* * *}$ & $-0.019^{* * *}$ & $-0.0186^{* * *}$ & $-0.0189^{* * *}$ \\
\hline & $(0.0018)$ & $(0.0017)$ & $(0.0017)$ & $(0.0056)$ & $(0.0054)$ & $(0.0052)$ \\
\hline \multirow[t]{2}{*}{ Unemployment Compensation } & $-0.0392^{* * *}$ & $-0.0390^{* * *}$ & $-0.0562^{* * * *}$ & $-0.0497^{* * * *}$ & $-0.0541^{* * *}$ & $-0.0566^{* * * *}$ \\
\hline & $(0.0044)$ & $(0.0047)$ & $(0.0051)$ & $(0.0093)$ & $(0.011)$ & $(0.011)$ \\
\hline \multirow[t]{2}{*}{ Sickness Pay } & -0.000122 & $-0.0070^{* * *}$ & $-0.0064^{* *}$ & -0.00769 & $-0.0144^{* * *}$ & $-0.0124^{* *}$ \\
\hline & $(0.0026)$ & $(0.0027)$ & $(0.0026)$ & $(0.0063)$ & $(0.0053)$ & $(0.0051)$ \\
\hline \multirow{2}{*}{ Subsidies } & $-0.0300^{* * * *}$ & $-0.0317^{* * *}$ & $-0.0092^{*}$ & $-0.0343^{* * *}$ & $-0.0408^{* * * *}$ & $-0.0388^{* * * *}$ \\
\hline & $(0.0042)$ & $(0.0043)$ & $(0.0051)$ & $(0.012)$ & $(0.012)$ & $(0.012)$ \\
\hline
\end{tabular}


Table10(a) Individual Country Estimates

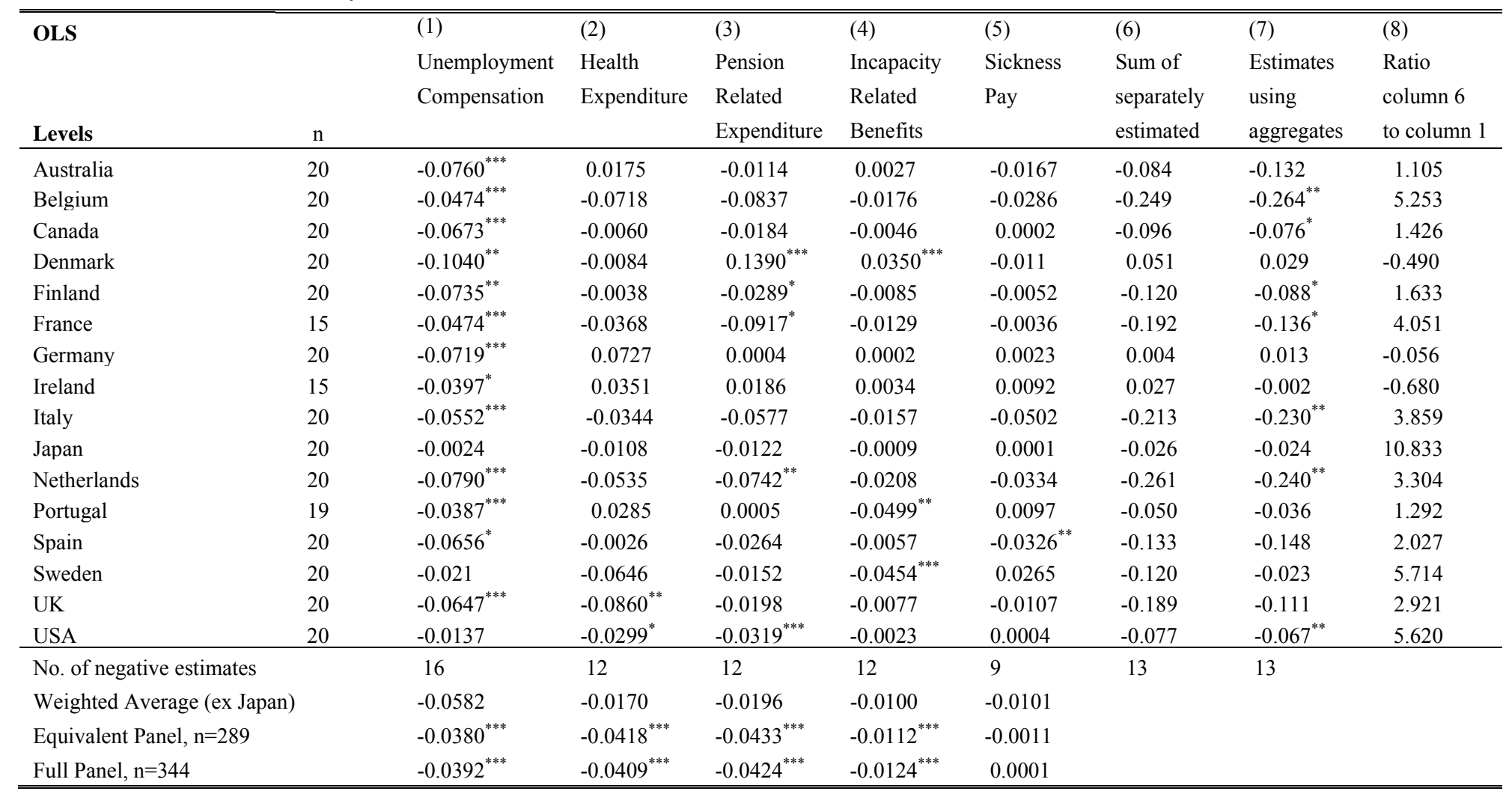

Notes; as Table 2. Source: authors' own calculations. 
Table10(b) Individual Country Estimates

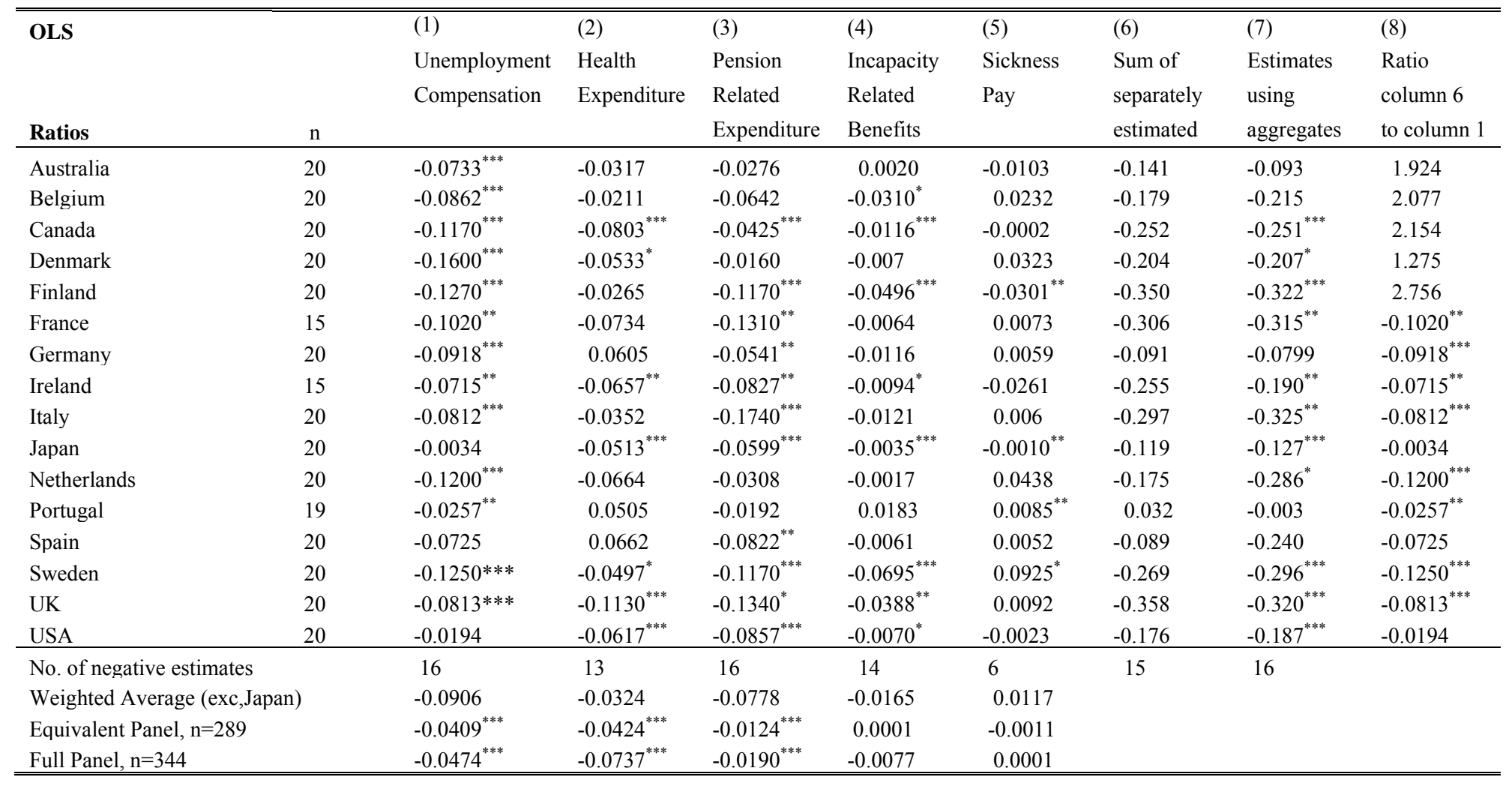

Notes; as Table 2. Source: authors' own calculations. 
Upon first glance at both parts of this table, in levels and ratios (parts 10a and 10b), it is difficult not to be struck by the lower frequency of significant results than occurred in estimates for the 20 country panel. Of course, this is especially true in levels. The other striking result is that unemployment compensation is the only social expenditure for which significant results persist consistently in levels and ratios. For the rest of the expenditures any consistency is in ratios. Nothing in the earlier estimates or the raw data necessarily prepared us for this last outcome. The coefficients and Student $t$ s for the other social categories besides unemployment compensation were often as high and the raw data in Table 1 showed higher averages and higher ratios of averages to international dispersion - more international uniformity - for some of the other categories.

In interpreting the results, let us call attention first to the last three rows of the table (both parts). These rows compare the average of the estimates in the individual country tests in the first row with the two corresponding panel estimates in the next two rows. The first of these next two rows refers to the panel data estimates relating to the identical 289 observations as in the individual country results after excluding Japan. The next one (on the last of the three rows) repeats the preceding panel data estimates covering all 344 observations for all 20 countries in Table 3 . The results for those 2 panel estimates match well - a comfort in itself. However, the first of these three rows, relating to the individual-country tests, shows some important differences with the last two. The averages of the single-country estimates for unemployment compensation are above the panel data ones both in levels and ratios. The opposite is true for health spending, where the averages of the individual country estimates are below the panel data ones both in levels and ratios though they are much closer in ratios. In the case of pensions, the averages of the single country estimates are lower in levels but higher in ratios. Finally, as concerns incapacity pay and sickness pay, there is little difference between the three rows. All in all, the averages of the single country estimates correspond roughly with the panel data estimates.

We have also constructed a table of individual-country results for the previous 16 countries going up to 2003 that corresponds exactly to the estimates in the previous Table 9 (all the data is the same). This is Table A2 of the Test Appendix. There are 2 more observations per country in these next results, that is, there should be. Curiously enough, this is not true for Australia, where there are 8 fewer observations, and for Ireland, where there are 3 fewer. The reason is that some earlier observations were removed for both countries in the 2007 release. The bottom 3 rows of this next table then read exactly the same way as the bottom 3 rows of Table 10. All the earlier conclusions follow exactly except that unemployment compensation yields the same result in all three rows in levels.

Continuing with the analysis in Table 10, it would be possible to ascribe the poorer quality of the separate estimates for the individual countries largely, if not entirely, to lower sample size and to smaller statistical variance of the observations. However, the results may also merit the conclusion that the significance of the contribution of unemployment compensation to automatic stabilisation is more uniform than that of the other social spending programs. Suppose we take this interpretation for granted. Even then, the contribution of the other social programs cannot be neglected. In developing this point, let us begin with levels.

As regards the levels specification, Table 10a, one general indicator of the importance of cyclical responses of other categories of social spending besides unemployment compensation is 
the ratio of the sum of the individual estimates of all 5 social categories to unemployment compensation alone. This is the ratio of column 6 to column 1 shown in column 8 . Those ratios are close to 3 to 1 for 8 of the 16 countries. True, in a number of the other 8 cases the ratios are close to one and even negative in 3 of them. But upon examination, except for Denmark, these are generally instances where health spending is pro-cyclical but insignificant, and this factor alone can account for the low and negative ratios. Denmark seems to us the only instance where the OLS results in levels are truly puzzling. Besides the negative ratio in column 8 , the Danish results show highly significant destabilising effects for pensions and incapacity benefits in levels (but not ratios), contrary to the panel data results. ${ }^{6,7}$ There are also some significant coefficients relating to health expenditures, pensions and incapacity pay in the country estimates - especially for pensions - in levels in the table. Of particular note, unemployment compensation is of no importance at all in the OLS estimates in levels for the US and Japan, while both health expenditures and retirement benefits are highly significant in the US. Sweden is interesting too in showing an insignificant coefficient for unemployment compensation but a significant one for incapacity pay.

However, the situation in ratios argues our case forcefully. All 16 individual signs for pensions are stabilising (negative), 14 of them are so for incapacity pay and 13 for health spending. Only a single coefficient in column 8 is notably below one and only one of the others is close to one, both of them are also cases where health expenditures are strongly positive but insignificant. Significant coefficients abound for health, pensions, and incapacity benefits, all of which go in the stabilising direction, in accordance with the panel estimates. There are also 4 significant signs for sickness pay, though they go in opposite directions. Some of the country-by-country results in ratios deserve mention too. Health, pensions and incapacity benefits are all significantly stabilising at the 1 percent confidence level in Canada along with unemployment compensation. The same is true for Sweden and the UK, except that in each country one of the 4 coefficients is only significant below the 1 percent confidence level. Both Japan and Finland are interesting: in both cases all social spending categories including sickness pay are significantly stabilising except for unemployment compensation in Japan and health spending in Finland. Table A2 shows that the individual country estimates for 1982-2003 corroborate those for 1982-2001 and reinforce the previous remarks.

In sum, despite the poorer quality of the individual-country estimates, we conclude that these estimates reinforce the conclusions based on the panel data ones in arguing for the importance of admitting other social benefits to households besides unemployment compensation in analysing automatic stabilisation.

\footnotetext{
${ }^{6}$ Still, as seen in table A1 of the appendix, the presence of Denmark does not much affect the panel results either in levels or in ratios. Further, Table A2a of the appendix shows that when we re-estimate for 1981-2003, the positive and significant response of invalidity pay in levels disappears.

${ }^{7}$ We also checked on the reliability of column 6 with the use of column 7, where the estimation treats social spending as a single aggregate. The results in this next column differ little from column 6 with the exception of Sweden in levels and Spain and the Netherlands in ratios. This supports our attention to column 6.
} 


\section{DISCUSSION}

\subsection{The implications for automatic versus discretionary policy}

The policy implications are important. Two outstanding points of reference in the discussion of European fiscal policy both rely on the official figures for automatic stabilisation: Buti and Sapir, eds. (1998) and Gali and Perotti (2003). Buti and Sapir, eds. (1998) do so in a large-scale study of fiscal policy behaviour by the Services of the European Commission shortly before entry into monetary union. In this study, the authors interpret the policy behaviour of the prospective EU membership in the preceding decades as destabilising during episodes of moderate positive output gaps. However, if automatic stabilisation was higher than they assumed, as our analysis says, the expansionary destabilising behaviour was even greater at these times, since it offset stronger forces that work automatically the opposite way. ${ }^{8}$ Gali and Perotti (2003) for their part conclude that, if anything, discretionary fiscal policy in the EU became more stabilising following the Maastricht Treaty. Our results water down this last conclusion since there was less discretionary stabilisation than they assumed.

\subsection{The implications for the Stability and Growth Pact and Reforms}

Our results also call into question the Buti-Sapir assessment that the 3 percent ceiling on government deficits in the Stability and Growth Pact (SGP) would only bite significantly in Member States of the EU facing a sharp recession at a point when they are already close to the ceiling. Of course, cross-country variations in automatic stabilisation affect this conclusion. But even so, quite apart, if the contribution of automatic stabilisation is some 20 to 30 percent higher on average than Buti and Sapir thought, the chances of exceeding the ceiling are notably higher. This may explain some of the difficulty various Member States of the EU have encountered in meeting the ceiling thus far. It may also lend support to the 2005 SGP reforms.

Furthermore, as a part of the SGP, the European Commission has a mandate to survey the Medium Term Budgetary Forecasts of the member countries in order to check whether deficits have been accurately projected and the ceilings will be met. If our analysis is correct, the reports of the Commission to the European Council tend to downplay the automatic forces influencing the budget and to give discretionary fiscal policy too much credit for automatic movements in the net government surpluses. True, both the plans that are submitted to the Council by the Member States and the reports to the Council by the Commission pay increasing attention to other social payments and transfers besides unemployment compensation, particularly in the context of the discussions of pension reform. This is then reflected in the Council's assessments. However, the focus of this attention is on sustainability or the long run. In our view, the implications for the short run

\footnotetext{
${ }^{8}$ In an earlier study that focused on discretionary fiscal policy, Melitz (2000) found the destabilizing tendency of government expenditures to be so precisely defined that he interpreted the results as reflecting automatic rather than discretionary policy. Obviously neither author any longer accepts this view. Our basic inference is that it is impossible to draw inferences about automatic fiscal policy in a study of fiscal policy without modelling automatic fiscal policy separately.
} 
adjustment process are of crucial importance too. We would argue that the neglect of the cyclical implications of pensions, health expenditure and disability pay, especially in evaluating alternative reform packages, could be storing up problems for the control of budgets in the future.

\subsection{Heterogeneity across countries}

Evidently our study also has consequences for the differences in automatic stabilisation between countries across the EU. Chapter 9 of Buti and Sapir (1998) is a good source of the official view of these differences. The general idea is that the big member countries are fairly representative and cluster around the average level of 50\% automatic stabilisation, while the Netherlands and some of the Scandinavian countries are at the top of the ranking with closer to 80 or $90 \%$ stabilisation.

(These differences narrow after taking into account the stabilising impact of net government surpluses on output since the smaller countries are also more open and subject to bigger "leakages" abroad.) However, even on a cursory glance at the individual country results in Table 10 (which are only partial since they concern strictly social spending inclusive of health expenditure), this familiar picture ceases to be evident. There are large differences in the stabilising effects of social spending between Member States of the EU while the official estimates of automatic stabilisation are primarily grounded on tax receipts.

Of course, another big topic arises from the imprecision of the cross-country estimates of the cyclical sensitivity of the various social spending programs in our discussion. An important part of the reason could well be that the cyclical sensitivity varies by country. Why might this be true? On this fundamental issue, we shall only be suggestive and more research needs to come.

\subsubsection{Retirement Benefits}

In the case of retirement benefits, the incentives of firms to encourage early retirement during recessions are likely to depend heavily on features of payroll taxes, compulsory contributions to pension plans, entitlement rules and social security payments (see Hutchens (1998)). Since these features differ across countries, we could expect their effects on retirements to be more pronounced in some countries than others. As observed earlier, two recent studies find evidence that low demand for labour in recessions affects transitions from labour participation into retirement. Coile and Levine (2006) do so for the US and Hakola and Utusitalo (2005) for Finland. Interestingly, the US and Finland are also countries where the stabilising behaviour of retirement pay shows up in our results both in levels and ratios. As a further consideration, firms may be better able to discriminate more against older workers in deciding about layoffs in some countries than others because of differences in labour regulations and trade union power.

\subsubsection{Health Spending}

Health expenditures, in turn, are disproportionately high for the elderly and there could be a link to pensions. Those who retire early during recessions may have poorer health (see Dwyer and Mitchell (1999)). With retirement, they also have more time for health care. Retirees generally may devote more attention to health care. Their health itself could be affected by retirement and 
not necessarily for the better. Thus, the cyclical behaviour of pensions and health spending may be correlated. Indeed, there is an interesting positive correlation between the incidence of the stabilising behaviour of pension pay and health spending in our results in Table 10b in ratios. This correlation is weaker in ratios (stronger in levels) in Table A2b (going up to 2003) than in Table $10 \mathrm{~b}$ but appears there too. Other factors may matter as well. The extent of public health insurance varies somewhat internationally. Note as well that governments may differ in their ability to control their spending on health in the short run. While this ability is probably fairly modest everywhere, in some countries, such as France, errors in projections of total public spending repeatedly lead to modifications of the system of public health protection. Could it be that the US, Canada, the UK, Ireland and Japan, where health insurance shows up as particularly stabilising in ratios in our results (except for Ireland, in Table A2b as well), are ones where public control over total health spending in the short run is especially feeble?

\subsubsection{Incapacity and sickness related Benefits}

The importance of national rules in determining the cyclical behaviour of incapacity benefits is particularly plain. It may be that people with temporary health problems may qualify for disability pay in some countries but not others. The financial incentives to return to work once receiving disability pay may also differ. Short spells of disability pay may not be equally possible everywhere. Autor and Duggan (2006) discuss in rich detail how the efforts by the Social Security Administration in the US to enforce strict medical criteria have been thwarted by the courts in litigations. Of course, in countries where tenuous applications for incapacity benefits may succeed, the benefits may be more closely linked to the cycle.

In the case of sickness pay, our cross-country results are particularly divided. But some of the international differences make sense. The two countries that show significantly positive and destabilising coefficients for sick pay in Table 10b, Portugal and Sweden, are the subject of particular discussion of the disincentives to report sick in recessions for people holding temporary employment contracts. Spain should be possibly considered in this connection too since this country has a particularly high share of workers holding temporary contracts in the EU and a positive coefficient for sickness pay (though moderate and insignificant). ${ }^{9}$ Spain, Portugal and Sweden all feature heavily in the literature on the implications of increased use of temporary versus permanent contracts (see, for example Bentolila and Saint-Paul (1992), Bentolila and Dolado (1994), Jimeno and Toharia (1996), Bover et al (2000) and Arai and Skogman Thoursie (2005) and compare Table A2(b)).

\subsection{General influences on stabilising behaviour}

The fact that health expenditures, retirement benefits and invalidity benefits all became more

\footnotetext{
${ }^{9}$ In the third quarter of 2005, Eurostat Labour Force Survey data indicate that the share of employees with temporary contracts reached $14.7 \%$ in the EU15, ranging from $34.4 \%$ in Spain, $19.9 \%$ in Portugal and $17.3 \%$ in Sweden to under $10 \%$ in Austria, Belgium, Luxembourg and the UK; see Table 9 in Romans and Hardarson (2006). Note that Spain is also the one country with a significantly negative (stabilising) coefficient for sickness pay in Table 10a. (The same coefficient is still negative but insignificant in Table A2a.) In this case, our leaning toward the evidence in ratios is therefore particularly important.
} 
stabilising in the post 1992 period, according to the relevant robustness test in our work (only possible for the panel data) is also of considerable interest. One hunch would be that the same features that account for the importance of a social program in a country would help explain the rise in the importance of the program in the same country since the nineties. However, in addition, an inherent dynamic could exist. For example, demography may enter as a factor from one cycle to the next in the case of pension spending. Furthermore, political factors could play a role in the evolution of cyclical sensitivity. In particular, a political reluctance to rely more heavily on unemployment compensation could have something to do with the growing importance of invalidity pay. As another factor, the tier of government that is responsible for payment could matter. Budget constraints are generally tighter for sub-central tiers of governments than for central ones. Thus, if a lower tier pays, the cyclical responsiveness may be weaker. As one application, in the US unemployment compensation is financed exclusively by state governments. Could this be partly why unemployment compensation is not important and other sorts of social spending are in the US?

These are all merely suggestions. The question of the possible differences in the cyclical sensitivity of some social spending programs depending on the country has not been posed before, and while there are various international comparisons of social spending programs, we have found none that bear on the issue of the differences in cyclical sensitivity.

\subsection{Specifications in levels versus ratios}

Finally, our better results in ratios than in levels deserve discussion. The difference is striking. Most notable of all, our panel data results agree much better with our individual-country results in ratios than in levels. Strictly statistical explanations for these differences in results appeal to us most. Suppose that the variance of the individual receipts and spending items rises with their levels. Then dividing by output or potential output would yield more efficient estimates. ${ }^{10}$ In addition, suppose, as is probably true, that measurement errors in output, output gaps, and individual government receipts and expenditures are positively correlated. Then some errors in levels will cancel out after division by observed or potential output. In the end, therefore, we have a marked preference for the results in ratios on purely statistical grounds, even though, as mentioned earlier, theory alone gives us no reason for any preference. Notwithstanding, according to our earlier theoretical discussion, estimates in levels and ratios are both linear approximations to a common structural model that distort the results about the relative significance of receipts and expenditures in automatic stabilisation in opposite directions. In addition, reasoning about fiscal policy occasionally occurs in levels, and when it does, estimates in levels are more transparent. Therefore, further probing into the weaker results in levels - especially those in the individual country tests - would be desirable.

\footnotetext{
${ }^{10}$ True, the variance of the denominator in the ratio may also rise with its level, but nevertheless heteroscedasticity is likely to be less of a problem in ratios. It is also true that our use of robust standard errors should alleviate the problem of heteroscedasticity in the specification in levels, but it is very unlikely that the correction would be perfect.
} 


\section{CONCLUSION}

In this paper we have exploited detailed data from the OECD Social Expenditure Database along with the national accounts aggregates from the OECD Economic Outlook Database in order to reassess the extent and composition of automatic stabilisation. We found that automatic movements in health spending, pensions, and incapacity benefits are prominent along with unemployment compensation. This result was only to be expected in the case of pensions, and need not arouse surprise in the cases of health spending and incapacity benefits. Perhaps the stabilising nature of the cyclical movements of health spending and incapacity benefits could not have been foreseen. However, the hypothesis that either of these two categories of social spending is a-cyclical goes contrary to a good deal of previous theory and evidence, particularly in the fields of labour and health. In conclusion, we firmly reject the conjectures in earlier macro studies, such as those we quoted from Auerbach and Feenberg (2000), Galí and Perotti (2003), Perotti (2002), that unemployment benefits are the only current expenditures that contribute significantly to automatic stabilisation.

We have already pointed to several directions of further research. But in closing, we would like to mention one more: the welfare implications. Automatic stabilisation is generally conceived as a social benefit. However, if automatic stabilisation depends largely on health care, retirement age and propensity to claim incapacity for work, this is not as obvious as before. ${ }^{11}$ From the standpoint of smoothing lifetime consumption, stable health care is a good. It is therefore questionable to encourage institutional arrangements that condition health care on the business cycle. Subjecting retirement income to the hazards of the business cycle is also dubious. Even if the action should stabilise current output it may still not smooth lifetime consumption. Needless to say, inducing long term exits from the labour force for temporary reasons can do harm. The sources of automatic stabilisation we found in our discussion could thus worsen social welfare.

\footnotetext{
${ }^{11}$ Perhaps it was never obvious. For two different sorts of reservations about the welfare benefits, see Farina and Tamborini (2003) and Buti et al. (2003). We should also emphasise that we are by no means the first to raise welfare questions about the social spending programs we discuss.
} 


\section{REFERENCES}

Aghion, Philippe and Ioana Marinescu (in press), "Cyclical budgetary policy and economic growth: What do we learn from OECD panel data?" NBER Macroeconomics Annual, Volume 22.

Arai, Mahmood and Skogman Thoursie, Peter, 2005, "Incentive or Selection in Cyclical Absenteeism," Labour Economics, 12, 269-280.

Arreaza, Adriana, Bent Sørensen, and Oved Yosha, 1999, "Consumption smoothing through fiscal policy in OECD and EU countries," in James Poterba and Jürgen von Hagen, eds., Fiscal Institutions and Fiscal Performance, Chicago: University of Chicago Press, 59-80.

Auerbach, Alan and Daniel Feenberg, 2000, "The significance of federal taxes as automatic stabilizers," Journal of Economic Perspectives, Summer, 37-56.

Autor, David and Mark Duggan, 2003, "The rise in the disability rolls and the decline in unemployment," Quarterly Journal of Economics 118, No. 1, 157-205.

Autor, David and Mark Duggan, 2006, "The growth in the Social Security disability rolls: A fiscal crisis unfolding," Journal of Economic Perspectives, Summer, 71-96.

Barmby, Tim, Marco Ercolani, and John Treble, 2002, "Sickness Absence: An International Comparison," Economic Journal, 112, F315-F331.

Barmby, Tim, Marco Ercolani and John Treble, 2004, "Sickness Absence in the UK: 1984-2002," Swedish Economic Policy Review, 11, No. 1, 65-88.

Beatty, Christina, Stephen Fothergill and Rob Macmillan, 2000, "A Theory of Employment, Unemployment and Sickness," Regional Studies, 34, No. 7, 617-630.

Bentolila, Samuel and Juan J. Dolado, 1994, "Labour Flexibility and Wages: Lessons from Spain," Economic Policy, 9, No. 18, 53-99.

Bentolila, Samuel and Gilles Saint-Paul, 1992, "The macroeconomic impact of flexible labor contracts, with an application to Spain," European Economic Review, 36, 1013-1053.

Black, Dan, Kermit Daniel, and Seth Sanders, 2002, "The Impact of Economic Conditions on Participation in Disability Programs: Evidence from the Coal Boom and Bust," American Economic Review, 92, 27-50.

Blanchard, Olivier and Peter Diamond, 1990, "The Cyclical Behavior of the Gross Flows of US Workers," Brookings Papers on Economic Activity, 2, 85-143.

Blanchard, Olivier and Roberto Perotti, 2002, "An Empirical Characterization of the Dynamic Effects of Changes in Government Spending and Taxes on Output" Quarterly Journal of Economics, 117, 1329-1368.

Blau, David and Donna Gilleskie, 2001, "Retiree Health Insurance and the Labor Force Behavior of Older Men in the 1990s," Review of Economics and Statistics, 83, 64-80.

Boone, Jan and Jan van Ours, 2002, "Cyclical Fluctuations in Workplace Accidents," CEPR Discussion Paper 3655, subsequently published in revised form as "Are recessions good for workplace safety?” Journal of Health Economics, 2006, 25, 1069-1093.

Bound, John, and Richard Burkhauser, 1999, "Economic Analysis of Transfer Programs Targeted on People with Disabilities," in Orley Ashenfelter and David Card, eds., Handbook of Labor Economics, Volume 3C, Amsterdam: North Holland, 3417-3528.

Bover, Olympia, Pilar García-Perea, and Pedro Portugal, 2000, "Labour Market Outliers: Lessons from Portugal and Spain," Economic Policy, 31, 381-428.

Buti, Marco and André Sapir, eds., 1998, Economic Policy in EMU: A Study by the European Commission Services, Oxford: Clarendon Press.

Buti, Marco, Carlos Martinez-Mongay, Khalid Sekkat and Paul van den Noord, 2003, "Macroeconomic policy and structural reform: A conflict between stabilisation and flexibility?" in Marco Buti, ed., Monetary and Fiscal Policies in EMU - Interactions and Coordination, Cambridge: Cambridge University Press, chapter 6.

Canzoneri, Matthew, Robert Cumby and Behzad Diba, 2002, "Should the European central bank and the Federal Reserve be concerned about fiscal policy," Rethinking Stabilization Policy, a symposium sponsored by the Federal Reserve Bank of Kansas City, August, 333-389.

Coile, Courtney and Levine, Phillip, 2006, "Labor Market Shocks and Retirement: Do Government Programs Matter?" NBER Working Paper No. W12559, October.

Cohen, Darrel and Glenn Follette, 2000, "The Automatic Stabilizers: Quietly Doing Their Thing" Economic Policy Review, Federal Reserve Bank of New York, April, 35-67. 
Darby, Julia, Robert Hart and Michela Vecchi, 2001, "Labour force participation and the business cycle: a comparative analysis of France, Japan, Sweden and the United States," Japan and the World Economy, 13, 113-133.

Disney, Richard, Carl Emerson, and Matthew Wakefield, 2003, "Ill health and retirement in Britain: A panel data-based analysis," The Institute for Fiscal Studies WP03/02.

Dwyer, Debra and Olivia Mitchell, 1999, "Health problems as a determinant of retirement: Are selfrated measures endogenous?" Journal of Health Economics, 18, no. 2, 173-193.

European Commission, 2004, "Public Finances in EMU," Luxembourg: European Economy No. 3, Directorate-General of Economic and Financial Affairs, Office for Official Publications of the EC.

Farina, Francesco and Roberto Tamborini, 2004, " 'Set a sufficiently ambitious budget target and let automatic stabilizers work': Will it really work in the European Monetary Union?" Open Economies Review, 15, 143-168.

Galí, Jordi and Roberto Perotti, 2003, "Fiscal policy and monetary integration in Europe," Economic Policy, 37, October, 533-572.

Gerdtham, Ulf and Christopher Ruhm, 2006, "Deaths rise in good economic times: Evidence from the OECD," Economics and Human Biology, 4, No. 3, 298-316.

Giorno, Claude, Pete Richardson, Deborah Roseveare, and Paul van den Noord (1995), "Potential output, budget gaps, and structural budget balances," OECD Economic Studies 24, 167-209.

Girouard, Nathalie and Christophe André (2005), "Measuring Cyclically-adjusted Budget Balances for OECD Countries", OECD Economics Department Working Papers, No. 434.

Gruber, Jonathan and Brigitte Madrian, 1995, "Health Insurance Availability and the Retirement Decision," American Economic Review, 85, September, 938-948.

Hall, Robert and John Taylor, 1991, Macroeconomics: Theory, Performance and Policy, 3rd edition, New York: W.W. Norton \& Company.

Hall, Robert and David Pappell, 2005, Macroeconomics: Economic Growth, Fluctuations and Policy, sixth edition, New York: W.W. Norton \& Company.

Haveman, Robert and Barbara Wolfe, 1984, "Disability transfers and early retirement: A causal relationship?" Journal of Public Economics, 24, 47-66.

Holmlund, Bertil, 2004, "Sickness absence and search unemployment", Working Paper Series 2004:6, Uppsala University, Department of Economics.

Hutchens, Robert, 1999, "Social security benefits and employer behavior: evaluating social security early retirement benefits as a form of unemployment insurance," International Economic Review, 40, No. 3, 659- 678 .

Jimeno, Juan and Luis Toharia, 1996, "Effort, absenteeism, and fixed term employment contracts", Revista Española de Economia, 13 (1), 105-119.

Johannesson, Magnus and Ulf Gerdtham, 2005, "Business cycles and mortality: Results from Swedish micro data", Social Science and Medicine, 60, 205-218.

Johansson, Edvard, Petri Böckerman, Ritva Prättälä and Antti Uutela, 2006, "Alcohol-related mortality, drinking behavior, and business cycles - Are slumps really dry seasons?” European Journal of Health Economics, 7, No. 3, 212-217.

Kaivanto, Kim, 1997, “An alternative model of pro-cyclical absenteeism,” Economics Letters, 54, 29-34.

Khan, Jahangir, Ulf-G. Gerdtham, and Bjarne Jansson, 2004, "Effects of Macroeconomic Trends on Social Security Spending Due to Sickness and Disability," American Journal of Public Health, November, 94, No. 11, 2004-2009.

Leigh, J. Paul, 1985, "The effects of unemployment and the business cycle on absenteeism," Journal of Economics and Business, 37, 159-170.

McVicar, Duncan, 2006, "Why do disability benefit rolls vary between regions? A review of evidence from the US and UK," Regional Studies, 40, No. 5, 519-533.

Melitz, Jacques, 2000, "Some cross-country evidence about fiscal policy behaviour and consequences for EMU," European Commission, European Economy, Reports and Studies, Public Debt and Fiscal Policy in EMU, no. 2, Chapter 1.

Melitz, Jacques, 2006, "Non-discretionary and automatic fiscal policy in the EU and the OECD," in Servaas Deroose, Elena Flores, Alessandro Turrini and Paul Wierts, eds., Fiscal surveillance in EMU: New Issues and Challenges, Palgrave and the European Commission, Chapter 4.

Mitchell, Olivia and Gary Fields, 1984, "The effects of social security reforms on retirement ages and retirement incomes," Journal of Public Economics, 25 (November), 143-159. 
Neumayer, Eric, 2004, “Recessions Lower Some Mortality Rates: Evidence from Germany,” Social Science \& Medicine, 58, No. 6, 1037-1047.

Neumayer, Eric, 2005, "Commentary: The economic business cycle and mortality," International Journal of Epidemiology, 34, No. 6, 1221-1222;

Perotti, Roberto, 2002, "Estimating the Effects of Fiscal Policy in OECD Countries," European Central Bank Working Paper no. 168.

Rebick, Marcus, 1994,'Social security and older workers' labor market responsiveness: The United States, Japan, and Sweden" in Rebecca Blank, ed., Social protection versus economic flexibility: Is there a tradeoff? The University of Chicago Press, chapter 7.

Romans, Fabrice and Ómar Harđarson (2006) Statistics in Focus: Population and Social Conditions 6/2006, Eurostat. http://epp.eurostat.ec.europa.eu/cache/ITY_OFFPUB/KS-NK-06-006/EN/KSNK-06-006-EN.PDF

Ruhm, Christopher, 2000, “Are recessions good for your health?” Quarterly Journal of Economics, $115,617-650$.

Ruhm, Christopher, 2001, "Economic expansions are unhealthy," Working Paper, University of North Carolina.

Ruhm, Christopher, 2003, "Good times make you sick," Journal of Health Economics, 22, No. 4, 637-658.

Ruhm, Christopher, 2005a, "Healthy living in hard times," Journal of Health Economics, 24, No. 2, March, pp. 341-63.

Ruhm, Christopher, 2005b, "Commentary: Mortality increases during economic upturns," International Journal of Epidemiology, 34, No. 6, December 2005, 1206-1211.

Ruhm, Christopher, 2006, "Macroeconomic conditions, health and mortality," 5-16, in Andrew Jones, ed., Elgar Companion to Health Economics, Cheltenham, UK: Edward Elgar Publishing.

Ruhm, Christopher, and William Black, 2002, "Does drinking really decrease in bad times," Journal of Health Economics, 21, No. 4, 659-678.

Shapiro, Carl and Joseph Stiglitz, 1984, "Equilibrium unemployment as a worker discipline device," American Economic Review, 74, no. 3, 433-444.

Tapia Granados, José, 2005a, "Increasing mortality during the expansions of the US economy," 1900-1996," International Journal of Epidemiology, 34, No. 6, 1194-1202.

Tapia Granados, José, 2005b, "Recessions and mortality in Spain, 1980-1997," European Journal of Population, 21, 393-422.

Taylor, John, 2000, "Reassessing discretionary fiscal policy," Journal of Economic Perspectives, Summer, 21-36.

van den Noord, Paul, 2000, "The size and role of automatic stabilizers in the 1990s and beyond," OECD Economics Department Working Paper no. 230, revised and abridged in Marco Buti, Jürgen von Hagen and Carlos Martinez-Mongay, The Behaviour of Fiscal Authorities, Palgrave: UK, Houndmills, Basingstoke and Hampshire, 2002, chapter 8. 


\section{Appendix - Data}

\begin{tabular}{|c|c|c|}
\hline Code & Description & Source \\
\hline GDP & Gross Domestic Product (Market prices), & Economic Outlook \\
\hline GDPTR & Potential Output, Total Economy, Current Prices & Economic Outlook \\
\hline PGDP & GDP Deflator & Economic Outlook \\
\hline IRL & Interest Rate, Long Term & Economic Outlook \\
\hline UNR & Unemployment Rate & Economic Outlook \\
\hline YPGT & Total Disbursements Government & Economic Outlook \\
\hline YPG & Current Disbursements, Government & Economic Outlook \\
\hline CGAA & Government Consumption & Economic Outlook \\
\hline SSPG & Social Benefits Paid by Government & Economic Outlook \\
\hline PSE & Public Social Expenditure & SocX \\
\hline PCB & Public cash benefits & SocX \\
\hline PSE-PCB & Benefits in Kind & SocX \\
\hline Residual & $\mathrm{SSPG}-\mathrm{PCB}$ & \\
\hline CAPOG & Net Capital Outlays & Economic Outlook \\
\hline HLTH & Health Benefits in kind & SocX \\
\hline YPEPG & Property Income Paid by Government & Economic Outlook \\
\hline TOCP & Other Current Transfers Paid by Government & Economic Outlook \\
\hline TSUB & Subsidies & Economic Outlook \\
\hline YRG & Total Current Receipts & Economic Outlook \\
\hline TYB & Direct Taxes, Business & Economic Outlook \\
\hline TYH & Direct Taxes, Households & Economic Outlook \\
\hline TIND & Indirect Taxes & Economic Outlook \\
\hline SSRG & Social Security Contributions Received by Government & Economic Outlook \\
\hline TOCR & Other Current Transfers Received by Government & Economic Outlook \\
\hline YPERG & Property Income Received by Government & Economic Outlook \\
\hline AGE & $\begin{array}{l}\text { Pension Related Cash Benefits } \\
=\text { Old Age Cash Benefits exc. early retirement pension } \\
\quad \text { [Code 100-Code } 112 \text { ] } \\
+ \text { Survivors Cash Benefits [Code } 200] \\
+ \text { Early Retirement pension [Code } 112 \text { ] }\end{array}$ & SocX \\
\hline ICR & $\begin{array}{l}\text { Incapacity Benefits (Disability, Occupational injury and } \\
\text { Disease, exc. sickness [Code 300-Code } 313 \text {-Code } 314]\end{array}$ & SocX \\
\hline SIC & $\begin{array}{l}\text { Paid Sick Leave (occupational injury and disease and other } \\
\text { sickness daily allowances) [Code } 313+\text { Code } 314]\end{array}$ & SocX \\
\hline UC & Unemployment Compensation/Severance Pay [Code 711] & SocX \\
\hline OTH & $\begin{array}{l}\text { Other Social Cash Benefits }=\text { Family }+ \text { Housing }+ \text { Other } \\
{[\text { Code } 500+\text { Code } 800+\text { Code } 900]}\end{array}$ & SocX \\
\hline DPR & Dependency Ratio $=\frac{100(\text { population aged } 0-14 \text { and } 65+)}{\text { Population aged } 15-64}$ & ILO \\
\hline PAR & Prime Age Population Ratio $=\frac{\text { population aged } 25-54}{\text { total population }}$ & ILO \\
\hline FPR & Female Participation Rate & ILO \\
\hline
\end{tabular}

Economic Outlook $=$ OECD Economic Outlook Database as provided on the OECD Compendium CD Rom 2005 release 1.

SocX $=$ OECD Social Expenditure Database 2005 release.

ILO = International Labour Office Economically Active Population Estimates and Projections, 5th Edition.

All values are in current prices. 


\section{Appendix - Econometric Specification}

The full statement of the key equations we estimate for individual budgetary items is:

$$
\begin{aligned}
& \Delta \mathrm{x}_{\mathrm{i}}=\alpha_{\mathrm{oi}}+\alpha_{1 \mathrm{i}} \mathrm{t}+\alpha_{\mathrm{ti}}+\alpha_{\mathrm{ci}}+\beta_{1 \mathrm{i}} \Delta\left(\mathrm{Y}-\mathrm{Y}^{*}\right)+\beta_{2 \mathrm{i}} \Delta \pi+\beta_{3 \mathrm{i}} \mathrm{r}_{\mathrm{Lt}}+\beta_{4 \mathrm{i}} \Delta_{\mathrm{t}-1} \mathrm{x}_{\mathrm{i}}+\beta_{5 \mathrm{i}} \Delta_{\mathrm{t}-1}^{2} \mathrm{x}_{\mathrm{i}}+\varepsilon_{\mathrm{ti}} \\
& \Delta\left(\mathrm{x}_{\mathrm{i}} / \mathrm{Y}\right)=\alpha_{\mathrm{oi}}+\alpha_{1 \mathrm{i}} \mathrm{t}+\alpha_{\mathrm{ti}}+\alpha_{\mathrm{ci}}+\beta_{1 \mathrm{i}} \Delta\left(\mathrm{Y} / \mathrm{Y}^{*}\right)+\beta_{2 \mathrm{i}} \Delta \pi+\beta_{3 \mathrm{i}} \mathrm{r}_{\mathrm{Lt}}+\beta_{4 \mathrm{i}} \Delta_{\mathrm{t}-1}\left(\mathrm{x}_{\mathrm{i}} / \mathrm{Y}\right)+\beta_{5 \mathrm{i}} \Delta_{\mathrm{t}-1}^{2}\left(\mathrm{x}_{\mathrm{i}} / \mathrm{Y}\right)+\varepsilon_{\mathrm{ti}}
\end{aligned}
$$

for $\mathrm{i}=1 \ldots 15$.

As mentioned in the text, the $\mathrm{x}_{\mathrm{i}}$ variables refer to individual sorts of receipts and expenditures and there are then as many equations (1) and (2) as the number of $x_{i}$ (that is, 15 of them). $t$ refers to the time trend, $\alpha_{t}$ is a set of time fixed effects (year dummies), $\alpha_{c}$ is a set of country fixed effects, We also incorporate a German reunification dummy in level and first difference form to take account of the fact that the pre-unification data refers strictly to West Germany. $Y$ is annual output, $\mathrm{Y}^{*}$ is the OECD series for potential annual output, $\pi$ is the rate of inflation, and $r_{L}$ is the long term interest rate. As far as these two variables are concerned, the results are little affected by the use of levels or first differences. We kept the interest rate in levels while stating inflation in first differences in conformity with the rest of the specification. Our reason for keeping the interest rate in levels is that any automatic influence of this variable on the government budget would depend largely on initial debt and therefore could be cumulative. If so, the first difference of the budget balance would affect the first difference of the budget balance as well as the level. We experimented with the short term and the long term interest rate in the OECD database, and the long term one is much more important. We also included the lagged level and lagged first difference of the dependent variable since current responses may result partly from lagged responses of the dependent variable. As a further guard against omitted variable bias, we experimented with a number of non-policy conditioning variables that are not shown in the equations. These refer to the dependency ratio, the proportion of the population aged 25-54 and the female participation rate, expressed alternatively in levels and first differences. Finally, as regards ratios or equations (2), we decided to divide by observed output rather than potential output, since in any shift of focus to ratios, estimates of the automatic effects of the cycle on the original data deserve priority, in our opinion.

Because government tax and spending responses to the cycle may reciprocally affect the cycle itself, we also instrumented the output gap, and for the same reason, we instrumented inflation and the interest rate too. Our instruments for the output gap, inflation and the interest rate include contemporaneous oil price inflation in order to capture the important exogenous supply shocks during the study period, along with lags of the endogenous variables - namely, government current expenditures and revenues and aggregate OECD GDP - plus the lagged change in the proportion of the population not working, and the contemporaneous change in exports as a percentage of GDP. In addition, we included lags of the instrumented variables themselves and country and time fixed effects in the instrumenting equations. The $\mathrm{R}^{2}$ from the instrumenting regressions indicate a reasonable fit in all the relevant equations. These $\mathrm{R}^{2}$ are $0.46,0.54 .0 .42$ and 0.94 for the change in the output gap in levels, the change in the gap in ratios, the change in inflation and the long term 
interest rate respectively. In addition, the significance of fit is confirmed by F tests. Finally, the residuals of the individual tax and spending equations are unlikely be independent. Thus, we employed 3SLS in identifying automatic stabilisation.

Note that fiscal policy research frequently focuses on the primary government balance rather than the observed one while we use the observed balance and introduce the interest rate as a separate explanatory variable. In fact, we do not have particularly strong views on this topic. However, it would be wrong to suppose that because of our choice, the outstanding net government debt drops out of our analysis. This debt is the sum of a starting value minus the cumulated value of net government surpluses over the study period (based on the consolidated government accounts including the central bank). Our country fixed effects incorporate any influence of the starting values of the debt in our analysis, while we explicitly admit the lagged values of net government surpluses. 
Table A1(a) Sequentially dropping each country in turn)

\begin{tabular}{|c|c|c|c|c|c|c|c|c|c|c|c|c|}
\hline \multirow{2}{*}{$\begin{array}{l}\text { 1981-2001 } \\
\text { Levels }\end{array}$} & \multirow[b]{2}{*}{$\mathrm{n}$} & \multicolumn{4}{|l|}{ Revenues } & \multicolumn{7}{|l|}{ Expenditure } \\
\hline & & $\begin{array}{l}\text { Household } \\
\text { Direct } \\
\text { Taxes }\end{array}$ & $\begin{array}{l}\text { Other } \\
\text { Direct } \\
\text { Taxes }\end{array}$ & $\begin{array}{l}\text { Social } \\
\text { Security } \\
\text { Contributions }\end{array}$ & $\begin{array}{l}\text { Indirect } \\
\text { Taxes }\end{array}$ & $\begin{array}{l}\text { Expenditure } \\
\text { n.e.s. }\end{array}$ & $\begin{array}{l}\text { Health } \\
\text { Expenditure }\end{array}$ & $\begin{array}{l}\text { Pension } \\
\text { Related } \\
\text { Expenditure }\end{array}$ & $\begin{array}{l}\text { Incapacity } \\
\text { Related } \\
\text { Expenditure }\end{array}$ & $\begin{array}{l}\text { Unemployment } \\
\text { Compensation }\end{array}$ & $\begin{array}{l}\text { Sickness } \\
\text { Pay }\end{array}$ & Subsidies \\
\hline All & 344 & $0.261^{* * *}$ & $0.144^{* * * *}$ & $0.0367^{* * *}$ & 0.0121 & $\begin{array}{l}-0.0164 \\
\end{array}$ & $-0.0409^{* * *}$ & $-0.0424^{* * *}$ & $-0.0124^{* * *}$ & $-0.0392^{* * *}$ & 0.0001 & $-0.0300^{\mathrm{nm}}$ \\
\hline Australia & 324 & $0.267^{* * *}$ & $0.119^{* * *}$ & $0.0399^{* * * *}$ & 0.0117 & -0.0130 & $-0.0394^{* * * *}$ & $-0.0374^{* * *}$ & $-0.0127^{* * *}$ & $-0.0379^{* * *}$ & -0.0012 & $-0.0291^{* * * *}$ \\
\hline Austria & 334 & $0.264^{* * * *}$ & $0.121^{* * * *}$ & $0.0378^{* * * *}$ & 0.0116 & -0.0147 & $-0.0410^{* * * *}$ & $-0.0425^{* * *}$ & $-0.0129^{* * *}$ & $-0.0376^{* * * *}$ & -0.0009 & $-0.0291^{* * * *}$ \\
\hline Belgium & 324 & $0.265^{* * *}$ & $0.122^{* * * *}$ & $0.0380^{* * * *}$ & 0.0126 & -0.0134 & $-0.0408^{* * * *}$ & $-0.0428^{* * *}$ & $-0.0130^{* * * *}$ & $-0.0374^{* * * *}$ & -0.0010 & $-0.0291^{* * *}$ \\
\hline Canada & 324 & $0.260^{* * * *}$ & $0.122^{* * * *}$ & $0.0387^{* * * *}$ & 0.0129 & -0.0171 & $-0.0415^{* * * *}$ & $-0.0436^{* * *}$ & $-0.0125^{* * * *}$ & $-0.0366^{* * *}$ & -0.0001 & $-0.0289^{* * * *}$ \\
\hline Denmark & 324 & $0.264^{* * * *}$ & $0.122^{* * * *}$ & $0.0339^{* * * *}$ & 0.0172 & -0.0234 & $-0.0409^{* * * *}$ & $-0.0364^{* * *}$ & $-0.0123^{* * * *}$ & $-0.0419^{* * * *}$ & 0.0006 & $-0.0279^{* * * * *}$ \\
\hline Finland & 324 & $0.264^{* * *}$ & $0.120^{* * * *}$ & $0.0384^{* * * *}$ & 0.0125 & -0.0132 & $-0.0409^{* * * *}$ & $-0.0426^{* * *}$ & $-0.0131^{* * * *}$ & $-0.0372^{* * * *}$ & -0.0011 & $-0.0288^{* * * *}$ \\
\hline France & 329 & $0.252^{* * * *}$ & $0.120^{* * * *}$ & $0.0388^{* * * *}$ & 0.0139 & -0.0058 & $-0.0419^{* * * *}$ & $-0.0397^{* * *}$ & $-0.0126^{* * * *}$ & $-0.0372^{* * * *}$ & -0.0008 & $-0.0272^{* * * *}$ \\
\hline Germany & 324 & $0.254^{* * * *}$ & $0.117^{* * * *}$ & $0.0401^{* * * *}$ & 0.0196 & 0.0061 & $-0.0399^{* * * *}$ & $-0.0451^{* * *}$ & $-0.0117^{* * *}$ & $-0.0355^{* * *}$ & -0.0008 & $-0.0319^{* * * * *}$ \\
\hline Iceland & 334 & $0.265^{* * * *}$ & $0.124^{* * * *}$ & $0.0387^{* * *}$ & 0.0194 & -0.0098 & $-0.0405^{* * * *}$ & $-0.0429^{* * *}$ & $-0.0124^{* * * *}$ & $-0.0385^{* * *}$ & -0.0007 & $-0.0284^{* * * *}$ \\
\hline Ireland & 329 & $0.264^{* * * *}$ & $0.121^{* * * *}$ & $0.0382^{* * * *}$ & 0.0133 & -0.0122 & $-0.0405^{* * * *}$ & $-0.0421^{* * *}$ & $-0.0129^{* * * *}$ & $-0.0374^{* * * *}$ & -0.0008 & $-0.0291^{* * * *}$ \\
\hline Italy & 324 & $0.269^{* * * *}$ & $0.121^{* * * *}$ & $0.0394^{* * * *}$ & 0.0169 & -0.0254 & $-0.0396^{* * * *}$ & $-0.0385^{* * *}$ & $-0.0129^{* * * *}$ & $-0.0375^{* * *}$ & -0.0008 & $-0.0290^{* * * *}$ \\
\hline Netherlands & 344 & $0.265^{* * *}$ & $0.122^{* * * *}$ & $0.0379^{* * * *}$ & 0.013 & -0.0159 & $-0.0409^{* * * *}$ & $-0.0423^{* * *}$ & $-0.0130^{* * * *}$ & $-0.0378^{* * * *}$ & -0.0008 & $-0.0292^{* * * * *}$ \\
\hline NewZealand & 324 & $0.264^{* * * *}$ & $0.122^{* * * *}$ & $0.0386^{* * * *}$ & 0.0128 & -0.0151 & $-0.0406^{* * * *}$ & $-0.0423^{* * *}$ & $-0.0138^{* * *}$ & $-0.0372^{* * * *}$ & -0.0011 & $-0.0298^{* * * *}$ \\
\hline Norway & 331 & $0.263^{* * * *}$ & $0.123^{* * * *}$ & $0.0390^{* * * *}$ & 0.0116 & -0.0143 & $-0.0403^{* * * *}$ & $-0.0420^{* * *}$ & $-0.0128^{* * * *}$ & $-0.0372^{* * * *}$ & -0.0008 & $-0.0291^{* * * *}$ \\
\hline Portugal & 332 & $0.261^{* * * *}$ & $0.176^{* * *}$ & $0.0347^{* * * *}$ & 0.00881 & -0.0090 & $-0.0434^{* * * *}$ & $-0.0432^{* * * *}$ & $-0.0127^{* * * *}$ & $-0.0374^{* * *}$ & -0.0008 & $-0.0308^{* * * *}$ \\
\hline Spain & 325 & $0.262^{* * * *}$ & $0.129^{* * * *}$ & $0.0403^{* * *}$ & 0.0165 & -0.0206 & $-0.0407^{* * * *}$ & $-0.0420^{* * *}$ & $-0.0129^{* * *}$ & $-0.0381^{* * * *}$ & -0.0007 & $-0.0294^{* * * *}$ \\
\hline Sweden & 324 & $0.265^{* * *}$ & $0.126^{* * * *}$ & $0.0354^{* * * *}$ & 0.0126 & -0.0125 & $-0.0412^{* * *}$ & $-0.0430^{* * *}$ & $-0.0131^{* * * *}$ & $-0.0374^{* * *}$ & -0.0007 & $-0.0292^{* * * *}$ \\
\hline Switzerland & 324 & $0.251^{* * * *}$ & $0.119^{* * * *}$ & $0.0361^{* * * *}$ & $0.0230^{* * *}$ & -0.0030 & $-0.0437^{* * * *}$ & $-0.0405^{* * *}$ & $-0.0086^{* * * *}$ & $-0.0316^{* * *}$ & $-0.0030^{*}$ & $-0.0155^{* * * *}$ \\
\hline UK & 334 & $0.264^{* * * *}$ & $0.120^{* * * *}$ & $0.0380^{* * * *}$ & 0.0128 & -0.0140 & $-0.0408^{* * * *}$ & $-0.0424^{* * *}$ & $-0.0129^{* * * *}$ & $-0.0383^{* * * *}$ & -0.0009 & $-0.0293^{* * * *}$ \\
\hline USA & 324 & $0.264^{* * * *}$ & $0.127^{* * * *}$ & $0.0348^{* * * *}$ & 0.0143 & -0.0108 & $-0.0426^{* * *}$ & $-0.0437^{* * *}$ & $-0.0135^{* * * *}$ & $-0.0376^{* * *}$ & -0.0005 & $-0.0293^{* * * *}$ \\
\hline
\end{tabular}


Table A1(b) Sequentially dropping each country in turn)

\begin{tabular}{|c|c|c|c|c|c|c|c|c|c|c|c|c|}
\hline \multirow{2}{*}{$\begin{array}{l}\text { 1981-2001 } \\
\text { Ratios }\end{array}$} & \multirow[b]{2}{*}{$\mathrm{n}$} & \multicolumn{4}{|l|}{ Revenues } & \multicolumn{7}{|l|}{ Expenditure } \\
\hline & & $\begin{array}{l}\text { Household } \\
\text { Direct } \\
\text { Taxes }\end{array}$ & $\begin{array}{l}\text { Other } \\
\text { Direct } \\
\text { Taxes }\end{array}$ & $\begin{array}{l}\text { Social } \\
\text { Security } \\
\text { Contributions }\end{array}$ & $\begin{array}{l}\text { Indirect } \\
\text { Taxes }\end{array}$ & $\begin{array}{l}\text { Expenditure } \\
\text { n.e.s. }\end{array}$ & $\begin{array}{l}\text { Health } \\
\text { Expenditure }\end{array}$ & $\begin{array}{l}\text { Pension } \\
\text { Related } \\
\text { Expenditure }\end{array}$ & $\begin{array}{l}\text { Incapacity } \\
\text { Related } \\
\text { Expenditure }\end{array}$ & $\begin{array}{l}\text { Unemployment } \\
\text { Compensation }\end{array}$ & $\begin{array}{l}\text { Sickness } \\
\text { Pay }\end{array}$ & Subsidies \\
\hline All & 344 & $\begin{array}{l}-0.0503 \\
\end{array}$ & 0.0010 & -0.0369 & -0.0020 & $-0.153 * * *$ & $-0.0474 * * *$ & $-0.0737 * * *$ & $-0.0190 * * *$ & $-0.0497 * * *$ & -0.0077 & $-0.0343^{\star \star \star}$ \\
\hline Australia & 324 & -0.0389 & -0.0038 & -0.0217 & -0.0100 & $-0.169 * * *$ & $-0.0401 * * *$ & $-0.0849 * * *$ & $-0.0230 * * *$ & $-0.0501 * * *$ & $-0.0106^{*}$ & $-0.0397^{\star \star \star}$ \\
\hline Austria & 334 & -0.0527 & 0.0023 & -0.0372 & -0.0067 & $-0.146^{* * *}$ & $-0.0459 * * *$ & $-0.0728^{* * *}$ & $-0.0184 * * *$ & $-0.0491 * * *$ & -0.0078 & $-0.0341^{\star \star \star}$ \\
\hline Belgium & 324 & -0.0223 & 0.011 & -0.0329 & -0.0090 & $-0.126 * * *$ & $-0.0522 * * *$ & $-0.0824 * * *$ & $-0.0175^{* * *}$ & $-0.0500 * * *$ & -0.0082 & $-0.0373^{\star \star \star}$ \\
\hline Canada & 324 & -0.0346 & -0.012 & -0.0369 & 0.0114 & $-0.152 * * *$ & $-0.0475^{* * *}$ & $-0.0791 * * *$ & $-0.0207 * * *$ & $-0.0534 * * *$ & -0.0091 & $-0.0397^{\star \star \star}$ \\
\hline Denmark & 324 & -0.0422 & 0.0068 & $-0.0453^{*}$ & 0.0018 & $-0.155^{* * *}$ & $-0.0525 * * *$ & $-0.0731^{* * *}$ & $-0.0205^{* * *}$ & $-0.0541 * * *$ & -0.0036 & $-0.0250^{\star \star}$ \\
\hline Finland & 324 & $-0.0725^{* *}$ & -0.0356 & -0.0248 & -0.0035 & $-0.189^{* * * *}$ & $-0.0365^{* * *}$ & $-0.0666^{* * * *}$ & $-0.0126^{* *}$ & $-0.0464^{* * *}$ & -0.0058 & -0.0200 \\
\hline France & 329 & $-0.0694^{* *}$ & -0.0005 & -0.0305 & 0.0077 & $-0.161^{* * *}$ & $-0.0474^{* * *}$ & $-0.0696^{* * *}$ & $-0.0199^{* * *}$ & $-0.0540^{* * *}$ & -0.0088 & $-0.0331^{\prime+x}$ \\
\hline Germany & 324 & -0.053 & 0.0073 & -0.0327 & -0.0030 & $-0.155^{* * *}$ & $-0.0444^{* * *}$ & $-0.0718^{* * *}$ & $-0.0175^{* * *}$ & $-0.0457^{* * *}$ & -0.0063 & $-0.0316^{*}$ \\
\hline Iceland & 334 & -0.0527 & 0.0042 & -0.0303 & -0.0053 & $-0.151^{* * * *}$ & $-0.0504^{* * *}$ & $-0.0707^{* * * *}$ & $-0.0184^{* * * *}$ & $-0.0531^{* * *}$ & -0.0089 & $-0.0364^{m+x}$ \\
\hline Ireland & 329 & -0.0465 & 0.0034 & -0.0394 & -0.0029 & $-0.146^{* * *}$ & $-0.0459^{* * *}$ & $-0.0721^{* * *}$ & $-0.0175^{* * *}$ & $-0.0486^{* * *}$ & -0.0035 & $-0.0351^{m+x}$ \\
\hline Italy & 324 & -0.0499 & -0.0151 & -0.0371 & -0.0020 & $-0.166^{* * *}$ & $-0.0487^{* * *}$ & $-0.0699^{* * *}$ & $-0.0182^{* * *}$ & $-0.0477^{* * *}$ & -0.0063 & $-0.0321^{m+x}$ \\
\hline Netherlands & 344 & -0.0503 & 0.0010 & -0.0369 & -0.0020 & $-0.153^{* * * *}$ & $-0.0474^{* * *}$ & $-0.0737^{* * * *}$ & $-0.0190^{* * * *}$ & $-0.0497^{* * *}$ & -0.0077 & $-0.0343^{\prime \prime}$ \\
\hline NewZealand & 324 & $-0.0570^{*}$ & -0.0098 & -0.0231 & -0.0160 & $-0.142^{* * *}$ & $-0.0417^{* * *}$ & $-0.0681^{* * * *}$ & $-0.0181^{* * *}$ & $-0.0529^{* * *}$ & -0.0060 & $-0.0365^{4+x}$ \\
\hline Norway & 331 & -0.0547 & 0.0083 & -0.0372 & -0.0025 & $-0.125^{* * *}$ & $-0.0496^{* * *}$ & $-0.0618^{* * *}$ & $-0.0133^{* *}$ & $-0.0450^{* * *}$ & -0.0085 & $-0.0338^{4+x}$ \\
\hline Portugal & 332 & -0.0493 & $0.0443^{*}$ & -0.0375 & -0.0205 & $-0.163^{* * *}$ & $-0.0501^{* * *}$ & $-0.0721^{* * *}$ & $-0.0174^{* * *}$ & $-0.0499^{* * *}$ & -0.0068 & $-0.0461^{+2+x}$ \\
\hline Spain & 325 & -0.0505 & 0.0166 & $-0.0481^{*}$ & -0.0158 & $-0.160^{* * *}$ & $-0.0453^{* * *}$ & $-0.101^{* * *}$ & $-0.0293^{* * *}$ & $-0.0544^{* * *}$ & -0.0114 & $-0.0280^{* *}$ \\
\hline Sweden & 324 & -0.0329 & -0.0003 & -0.0398 & -0.0099 & $-0.148^{* * *}$ & $-0.0468^{* * *}$ & $-0.0698^{* * * *}$ & $-0.0207^{* * *}$ & $-0.0469^{* * *}$ & -0.0057 & $-0.0323^{4+*}$ \\
\hline Switzerland & 324 & $-0.0623^{*}$ & 0.0048 & $-0.0451^{*}$ & 0.0128 & $-0.156^{* * *}$ & $-0.0454^{* * *}$ & $-0.0699^{* * * *}$ & $-0.0197^{* * * *}$ & $-0.0491^{* * *}$ & -0.0056 & -0.0358 \\
\hline UK & 334 & -0.0449 & 0.0016 & -0.0364 & -0.0028 & $-0.148^{* * *}$ & $-0.0484^{* * *}$ & $-0.0706^{* * *}$ & $-0.0192^{* * *}$ & $-0.0488^{* * *}$ & -0.0082 & $-0.0344^{+1+x}$ \\
\hline USA & 324 & -0.0568 & -0.0036 & -0.0364 & -0.0063 & $-0.157^{* * *}$ & $-0.0480^{* * *}$ & $-0.0717^{* * * *}$ & $-0.0213^{* * *}$ & $-0.0534^{* * *}$ & -0.0106 & $-0.0405^{-4 *}$ \\
\hline
\end{tabular}

Notes: see Table 2. Source: authors' own calculations. 
Table A2(a) Individual Country Estimates (based on 2007 release of Social Expenditure Data)

\begin{tabular}{|c|c|c|c|c|c|c|c|c|c|}
\hline \multirow[t]{3}{*}{ OLS } & \multirow[b]{4}{*}{$\mathrm{N}$} & \multirow{4}{*}{$\begin{array}{l}\text { (1) } \\
\text { Unemployment } \\
\text { Compensation }\end{array}$} & \multirow{4}{*}{$\begin{array}{l}(2) \\
\text { Health } \\
\text { Expenditure }\end{array}$} & \multirow{4}{*}{$\begin{array}{l}(3) \\
\text { Age } \\
\text { Related } \\
\text { Expenditure }\end{array}$} & \multirow{4}{*}{$\begin{array}{l}(4) \\
\text { Incapacity } \\
\text { Related } \\
\text { Benefits }\end{array}$} & \multirow{4}{*}{$\begin{array}{l}\text { (5) } \\
\text { Sickness Pay }\end{array}$} & \multirow{4}{*}{$\begin{array}{l}\text { (6) } \\
\text { Sum of } \\
\text { separately } \\
\text { estimated }\end{array}$} & \multirow{4}{*}{$\begin{array}{l}(7) \\
\text { Estimates } \\
\text { using } \\
\text { aggregates }\end{array}$} & \multirow{4}{*}{$\begin{array}{l}\text { (8) } \\
\text { Ratio } \\
\text { col. } 6 \text { to } \\
\text { to col. } 1\end{array}$} \\
\hline & & & & & & & & & \\
\hline & & & & & & & & & \\
\hline Levels & & & & & & & & & \\
\hline Australia & 12 & -0.0145 & $-0.0594^{*}$ & -0.0861 & -0.0136 & -0.0117 & -0.1853 & -0.0767 & 12.78 \\
\hline Belgium & 22 & $-0.0599^{* *}$ & -0.0556 & -0.0362 & -0.0083 & -0.0137 & -0.1737 & -0.1142 & 2.900 \\
\hline Canada & 22 & $-0.0647^{* * *}$ & -0.0166 & $-0.0097^{* *}$ & -0.0035 & 0.0002 & -0.0943 & -0.0306 & 1.457 \\
\hline Denmark & 20 & $-0.0971^{* *}$ & -0.0199 & $0.145^{* * *}$ & 0.0164 & -0.0204 & 0.0240 & 0.0689 & -0.247 \\
\hline Finland & 22 & $-0.0776^{* * *}$ & 0.0011 & -0.0305 & -0.0001 & -0.0048 & -0.1119 & -0.0216 & 1.442 \\
\hline France & 17 & $-0.0567^{* * *}$ & -0.0342 & $-0.0653^{*}$ & $-0.0056^{*}$ & $0.0060^{*}$ & -0.1558 & -0.1121 & 2.748 \\
\hline Germany & 22 & $-0.0728^{* * *}$ & 0.0633 & 0.0067 & 0.0039 & 0.0046 & 0.0057 & 0.0975 & -0.078 \\
\hline Ireland & 12 & $-0.0278^{* *}$ & -0.0387 & -0.0024 & 0.0189 & -0.0015 & -0.0515 & -0.0258 & 1.852 \\
\hline Italy & 22 & -0.0118 & -0.0065 & -0.0022 & -0.0238 & -0.0086 & -0.0530 & -0.0647 & 4.492 \\
\hline Japan & 22 & -0.0073 & -0.0109 & -0.0084 & 0.0008 & 0.0001 & -0.0257 & $-0.1551^{* * *}$ & 3.521 \\
\hline Netherlands & 22 & $-0.0721^{* * * *}$ & $-0.120^{* *}$ & $-0.0785^{* *}$ & -0.0290 & $-0.0352^{*}$ & -0.3348 & -0.3106 & 4.644 \\
\hline Portugal & 22 & $-0.0412^{* * *}$ & 0.0527 & -0.0002 & $-0.0270^{* *}$ & $0.0076^{*}$ & -0.0606 & -0.2071 & 1.470 \\
\hline Spain & 22 & $-0.158^{* *}$ & 0.0022 & -0.0349 & -0.0083 & -0.0223 & -0.2213 & 0.0483 & 1.401 \\
\hline Sweden & 22 & -0.0280 & 0.0112 & -0.0064 & $-0.0515^{* * * *}$ & 0.0132 & -0.0515 & -0.0021 & 1.829 \\
\hline UK & 22 & $-0.0892^{* *}$ & $-0.0947^{* *}$ & $-0.0741^{* * *}$ & -0.0031 & -0.0006 & -0.2617 & $-0.1791^{* * * *}$ & 2.934 \\
\hline USA & 22 & -0.0147 & $-0.0376^{* *}$ & $-0.0256^{* *}$ & -0.0032 & 0.0006 & -0.0632 & $-0.0516^{* *}$ & 4.299 \\
\hline No. of negative estimates & & 16 & 11 & 14 & 12 & 9 & 14 & 13 & \\
\hline Weighted Average (ex Japan) & & -0.0530 & -0.0178 & $-0,0164$ & $-0,0104$ & -0.0053 & & & \\
\hline Equivalent Panel, $n=325$ & & $-0.0563^{* * *}$ & $-0.0525^{* * *}$ & $-0.0397^{* * *}$ & $-0.0102^{* * *}$ & $-0.0054^{* *}$ & & & \\
\hline Full Panel, n=390 & & $-0.0562^{* * *}$ & $-0.0523^{* * *}$ & $-0.0395^{* * *}$ & $-0.0127^{* * * *}$ & $-0.0064^{* *}$ & & & \\
\hline
\end{tabular}

Notes: see Table 2. Source: authors' own calculations. 
Table A2(b) Individual Country Estimates (based on 2007 release of Social Expenditure Data)

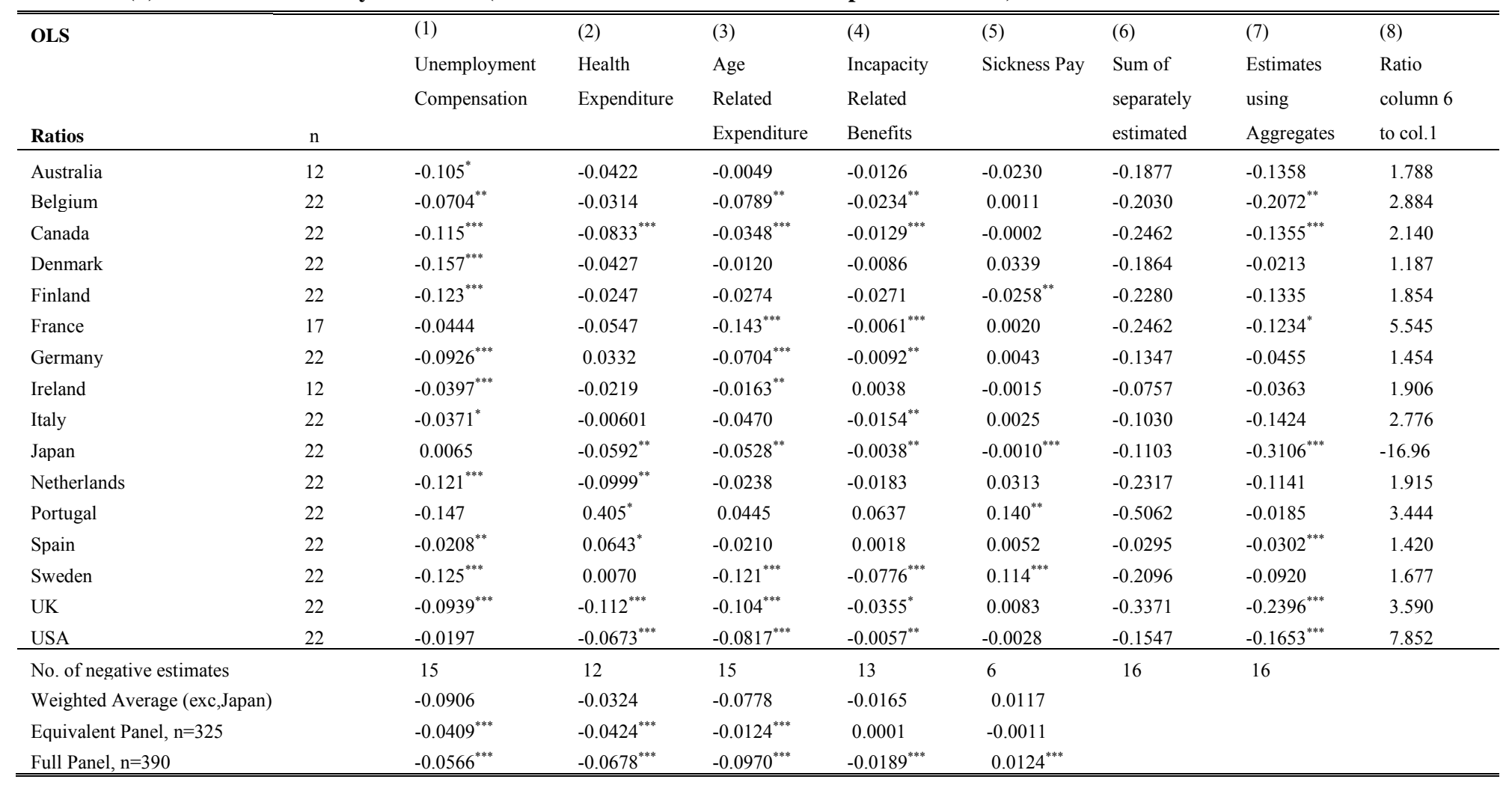

Notes: see Table 2. Source: authors' own calculations. 